\title{
A MULTI-LEVEL SOCIO-TECHNICAL SYSTEMS TELECOMMUTING FRAMEWORK
}

\begin{abstract}
Telecommuting can help create organizational efficiencies and improve competitive advantage. It has been studied from a variety of perspectives, including that of transportation, management, psychology, and information systems. However, telecommuting literature, while abundant and diversified, often reports contradictory results, creating dilemmas for practice and research. Past researchers noting such conflicting findings often identify the lack of guiding theoretical bases as a key problem. In an attempt to explain the contradictory results found in prior research and in practice, we review telecommuting literature and expose conceptualization issues that need to be addressed in the development of a telecommuting research model: telecommuting as both a context and an aspect of work, as a multi-level concept, and as a timedependent concept. The proposed multi-level model, guided by socio-technical systems theory, illustrates the inter-relationships of telecommuting antecedents and outcomes across levels of analysis and over time. The research offers a number of important implications for future research, as well as for managers involved in or affected by telecommuting in their organizations.
\end{abstract}

Keywords: telecommuting, telework, socio-technical systems, mobile work, multilevel research

\section{INTRODUCTION}

Telecommuting has become more popular than ever before due to the ubiquitous adoption of various information and communication technologies (ICT) like mobile computing devices, wireless hotspots, broadband into homes, etc. It has been used in organizations over the years to achieve organizational and individual benefits. Recent estimates by Gartner Dataquest suggest that 25\% of workers in the United States telecommuted in 2007 (Joli 2009). Other 
statistics suggest that the number of Americans who telecommuted at least one day per month for their employer increased from approximately 12.4 million in 2006 to 17.2 million in 2008. This represents a 74\% increase since 2005 (WorldatWork 2009). Similarly, while there were 2.2 million people telecommuting in the United Kingdom in 2003 (Smith 2004), it is estimated that more than one third of the United Kingdom workforce of 29 million telecommuted in 2007 (Pollster_YouGov_UK 2007).

Telecommuting, in this paper, focuses on the use of ICT to replace or substitute for work environments that require individuals to commute to a traditional office (Bélanger 1999). In line with other reviews of research in this area (e.g., Bailey and Kurland 2002; Bélanger and Collins 1998), we use the term telecommuting interchangeably with telework, which is a term more often used in Europe due to an initial focus on job creation as compared to a focus on environmental concerns in the United States (Sørensen et al. 2008). We are specifically interested in work performed away from the office by employees related to an established organization, which includes mobile work when tied to an organizational context but not small business owners whose place of business is only located in their home. Mobile work involves the use of mobile devices to conduct work from a variety of locations. Telecommuting has fundamentally changed the way organizations manage and conduct business, and how individuals and groups interrelate to accomplish work and reach desired work outcomes (Bélanger 1999; Pinsonneault and Boisvert 2001). Not surprisingly, then, telecommuting impacts cannot be considered solely from the point of view of the ICT usage. Rather, telecommuting involves complex interrelationships between telecommuting work environments, individual motivations, management and work practices, as well as ICT use. 
Telecommuting growth is a result of advances in ICT, as well as organizational attempts to increase internal efficiencies, improve competitive advantage, and respond to calls for flexibility in work hours (Hill et al. 2010; Pearce 2009). For example, mobile technology enables flexibility in the timing and location of work activities, and makes it easier to accommodate work and family (Towers et al. 2006). In addition, work is becoming increasingly global, as corporations outsource work activities or otherwise distribute interdependent activities across far-flung locations (Kuldeep et al. 2009). Performing work in this environment means that employees often work at home during non-traditional hours to communicate with their distributed colleagues.

Telecommuting literature includes studies from a variety of fields, such as transportation, management, psychology, and information systems. Because of this variety, the literature reveals a myriad of impacts on individuals, groups, and organizations that create unique problems for managing and facilitating telecommuting. This literature, while abundant, often reports contradictory results, creating dilemmas for practice and future research. For example, conflicting results are particularly evident in the effects of telecommuting on productivity. On the one hand, telecommuting is reported to have positive impacts on productivity at the individual, group, and organization levels through such work outcomes as increased performance, decreased office costs, lower absenteeism, and faster response times to customers (Bélanger and Collins 1998; Igbaria 1999; Pinsonneault and Boisvert 2001). However, at the same time telecommuting literature reports negative productivity impacts on individuals and groups, such as the absence of the best workers when needed, decreased individual productivity when working at home, problems using ICT, and a loss of synergy at all levels in the 
organization (Pinsonneault and Boisvert 2001; Ward and Shabha 2001; Watson-Manheim and Bélanger 2002).

Potential explanations for the conflicting results include methodological limitations, in particular the lack of theoretical bases underlying much of this research (Bailey and Kurland 2002; Bélanger and Collins 1998; McCloskey and Igbaria 1998). While a few attempts have been made to apply organizational theory to the study of telecommuting (Bailey and Kurland 2002; Desrochers et al. 2005; Mayo et al. 2009; Paez and Scott 2007; Virick et al. 2010; Ward and Shabha 2001; Workman et al. 2003), little evidence has emerged to help explain the conflicting findings found in the telecommuting literature.

The goal of this paper is to develop a conceptual model of telecommuting using a SocioTechnical Systems Theory (STS) foundation. In doing so, we review existing literature on telecommuting and identify three conceptualization issues we suggest should be addressed in the development of a strong theoretical framework for telecommuting: telecommuting is often considered a context only instead of an aspect of work, telecommuting is rarely considered as a multi-level concept, and the time-dependency of telecommuting outcomes is often ignored. In developing a framework that addresses these issues, our paper contributes to the literature by providing a new lens to explore telecommuting research questions.

The paper is organized as follows: first, we review existing telecommuting literature and highlight conceptualization issues that emerge from this literature. We then explore SocioTechnical Systems Theory as a foundation for the development of the multi-level conceptual model of telecommuting. We illustrate the use of the model with data from two organizations in the high technology industry before concluding with recommendations for future research.

\section{BACKGROUND}


There has been substantial research on telecommuting over the past decades as telecommuting started to gain acceptance in organizations. With few exceptions, empirical research on telecommuting started to appear in publications in the early 1980s. Rather than review the early literature, we turn to several in-depth reviews published between 1998 and 2003 to summarize prior telecommuting research before examining more recent telecommuting literature.

Table 1 shows the main findings of five literature reviews of telecommuting published in the last decade. The reviews conclude that telecommuting research largely has been nontheoretical highlighting the need for theoretical frameworks. This is not surprising as much of the early telecommuting research has taken the form of investigating its advantages and disadvantages. Two reviews note serious methodological weaknesses in the empirical studies conducted, including small sample pilot studies, only bivariate relationships studied, and a focus on cross-sectional surveys of users.

[Table 1]

A search of the various databases for telecommuting research from 2002 onward reveals a number of studies that explicitly address telecommuting or mobile work for employees related to an organization at least one day per week ${ }^{1}$ which are presented in Table 2.

[Table 2]

\footnotetext{
${ }^{1}$ The context of interest in this paper is work away from an office but related to the organization as opposed to full time home work. In the review, we also focused on empirical studies since the purpose of the review is mainly to identify conceptualization issues1.
} 
The brief review of recent literature likely does not show the full extent of research that has been published on telecommuting. Yet, in looking at both pre-2002 and recent telecommuting work, it is clear that issues are slowly emerging in the literature while the social and organizational environments are changing rapidly. These changes might be the result of individuals working longer and longer hours, or our transition to the digital economy where it is easier to transport work wherever one is, as long as ICTs are available. Indeed, the increased use of mobile technologies to communicate and access information has accelerated the blurring of lines between work and non-work activities (Axtell et al. 2008; Cousins and Robey 2005; Kakihara and Sørensen 2004; Towers et al. 2006).

Orlikowski and Barley (2001) point out that IT practitioner-focused literature has been consistently optimistic that the pervasive use of computers, and especially access to the Internet, has created conditions that should lead to substantial increases in the number of telecommuters. On the other hand, organizational theorists are pessimistic about the spread of telecommuting; pointing out that the work practice is contrary to well-established social and cultural understandings of how work takes place. Orlikowski and Barley (2001, p. 157) conclude: "Yet despite these insights, neither view comes to grip with the social dynamics of telecommuting because neither has investigated how people integrate telecommuting into their daily lives.” This is particularly important as social and organizational changes are taking place that further insert telecommuting into people's daily lives. For example, as more corporations have activities that span the globe, people increasingly work non-traditional hours, and much of this work takes place at home.

In a qualitative study of meetings taking place at Intel Corporation, Chudoba et al. (2011 ) found that participants were frequently from multiple, far-flung time zones, and expected to 
attend meetings outside of traditional work hours. The following example from their study is illustrative of the changes taking place. "While most respondents accepted the need for these meetings ... respondents devised interesting mechanisms to manage how the workday intruded on "personal” time. For example, respondent 6 noted that his wife also worked at Intel so they made use of each other's calendars to schedule time commitments for family responsibilities. For example, before accepting a late evening meeting, he might check his wife's calendar to see if she were available to pick up the children, and if so, add that commitment to her schedule so he could attend the evening meeting.”

Despite these significant changes in the way work is conducted, findings from our literature review indicate that researchers continue to more extensively focus on job satisfaction of telecommuters, adoption of telecommuting by individuals and organizations, impact on job satisfaction after adoption, and the relationship to work-family conflict. This may not be an unexpected trend; as Orlikowski and Scott (2008) point out, management research generally does not consider materiality of any kind and IT in particular. ${ }^{2}$ Moreover, there is usually a time lag between the surfacing of changes in the organizational work environment and the development of academic research addressing these new realities (Bélanger et al. 2002). However, we believe a core limitation of this research continues to be the lack of theoretical grounding due in part to the inherent complexity of the phenomenon. Telecommuting symbolizes a major shift in understanding of work and professional activities for individuals, organizations, and society, in addition to representing the deep penetration of ICT usage into the fabric of life at each level. Managers need to be better equipped to deal with and use telecommuting strategically in their

\footnotetext{
${ }^{2}$ We thank an anonymous reviewer for this insight.
} 
organizations. Moreover, enterprise-wide use of wireless technology and mobile devices will challenge management practices and stimulate changes in organizational design to accommodate the increasing ability to work anywhere, including remote locations (Sørensen et al. 2008).

In an effort to resolve some of the inconsistencies in previous studies, Gajendran and Harrison (2007) conducted a meta-analysis of 46 studies in which data were collected in natural settings involving a total of 12,883 employees. They find that telecommuting has largely beneficial consequences, both proximal, e.g., increased autonomy and lower work-family conflict, and distal, e.g., job satisfaction and performance. Some negative effects were found with high-intensity telecommuting (more than 2.5 days/week). In particular, relationships with co-workers appeared to be harmed. Hunton and Norman (2010) found that telework programs with the option of working at home or at a satellite office were associated with increased organizational commitment for employees while similar programs with only a full-time work at home option did not result in an increase. An ethnographic study by Whittle \& Mueller (2009) found significant dissatisfaction with telework expressed by a team of consultants at a high tech firm. However, the consultants espoused more positive feeling to their clients.

Other recent studies continue to investigate factors influencing telecommuting adoption. Perez et al. (2004) investigate why individual adoption of telecommuting has remained far below predicted levels. They argue that a stronger theoretical basis is needed to investigate problems in this domain and propose a model of telecommuting adoption based the technology acceptance model (TAM). The model is multi-level, focusing on ease of use and usefulness of telecommuting in the organization (supply side) instead of the usual measures of frequency of telecommuting by individuals (demand side). Several recent studies, i.e., Peters and Heusinkveld (2010), Hornung et al. (2009), have examined the role of the manager in the telecommuting 
adoption process. Peters and Heusinkveld (2010) found that the perception of improvements in work outcomes and social costs/benefits vary among managers from different 'occupational communities', e.g., CEOs' beliefs differ from HR managers'. Their findings suggest that telecommuting initiatives should pay much more attention to the institutional environment and managers' subcultures.

Khalifa and Davison (2008) investigate the usefulness of the Theory of Planned Behavior (TPB) to explain continuance of telecommuting by individuals after initial adoption. They find that habit can negatively moderate the relationship between attitude toward telecommuting and intention to telecommute. They also find that subjective norms, or the beliefs of the individual that important others think he should telecommute, have a moderate effect on intention. Others identify technology support as an important factor for employees to consider telecommuting (Baker et al. 2006), highlighting the importance of training for non-telecommuters.

Studies have also investigated work-related consequences of telecommuting for the individual, with findings that teleworking makes it much more difficult for employees to access tacit knowledge (Lee et al. 2007), that communications among teleworkers is reduced with better collaborative technologies but increasingly centralized around the manager of the teleworkers (Bélanger and Allport 2008), and that professional isolation among teleworkers is negatively associated with job performance and increases with time spent teleworking (Golden et al. 2008). Golden and Veiga (2005) investigate inconsistent findings in research on telecommuter job satisfaction. They found a curvilinear U-shaped relationship between the extent of telecommuting per week and job satisfaction, suggesting that certain jobs may become more difficult to perform effectively when telecommuting frequently. Golden (2007) found that prevalence of telecommuting is negatively associated with non-telecommuting co-worker 
satisfaction; this relationship is influenced by the amount of time co-workers telecommute, the extent of face-to-face interactions, and job autonomy. O’Neill (2009) found that there are differences in certain personality and motivational traits related to teleworker and non-teleworker effectiveness.

Researchers have continued to examine the interplay of consequences of telecommuting in work and non-work contexts. Golden (2006) found that the relationship between the extent of telecommuting and job satisfaction was mediated by quality of interactions in work-oriented and family-oriented relationships. Hartig et al. (2007) study the relationship between telecommuting and stress mitigation, and the potential effect on the restorative role of the home. Their findings indicate that teleworking women experience less effective restoration than their non-teleworking counterparts while men experience more effective restoration. Similarly, Araujo (2008) found that the use of ICT for to constructing space-time work patterns has different implications for each gender. Results suggest that ICT is more useful to men than women in organizing their space-time work patterns. In the context of nomadic computing, Cousins and Robey (2005) also found that professionals skilled at technology use were able to control the boundaries between their personal and business social contexts.

Other findings in this area include the fact that non-telecommuters have higher levels of work-family conflict, time-based conflict, strain-based conflict (strain from work activities limits participation in family activities) and higher perceptions of work interference with family than telecommuters; and male telecommuters have higher levels of behaviour-based conflict (behaviour effective in home-environment is counterproductive in work environment) than females (Madsen 2006). However, the use of mobile technology enables flexibility in the timing and location of the performance of work activities, and makes it easier to accommodate work and 
family (Sørensen and Al-Taitoon 2008; Towers et al. 2006). The use of this technology also increases expectations of colleagues in the work place and family members, leading to greater workload.

\subsection{Emerging Issues}

The literature review reveals several core telecommuting conceptualization issues that telecommuting theories need to address. Telecommuting conceptualization issues occur because researchers have failed to consider different aspects of the telecommuting context, such as timedependent and multi-level outcomes as suggested by Bailey \& Kurland (2002). For example, only one study to date has taken a truly multi-year approach (e.g., Hunton and Norman 2010), with a few longitudinal studies conducted across a timeframe of six months (Duxbury and Neufeld 1999; Ramsower 1985). Yet, time poses a challenge for this type of research. Telecommuting studies also have suffered from the lack of recognition of multiple levels of analysis. While only the most recent review specifically highlights this problem in prior telecommuting research, it is a core concept in organizational literature. In telecommuting, outcomes for telecommuters have effect on and are affected by their co-workers', managers', teams' and subordinates' outcomes (Pearlson and Saunders 2010). We discuss in the next sections these telecommuting conceptualization issues, and then use socio-technical systems (STS) theory as a guiding framework to develop the multi-level telecommuting conceptual model.

\section{CONCEPTUALIZATION ISSUES IN TELECOMMUTING RESEARCH}

The review reveals several limitations in the conceptualization of telecommuting: telecommuting as both a context and an aspect of work; telecommuting as a multi-level concept; and telecommuting as a time-dependent concept. 


\subsection{Telecommuting as an Embedded Aspect of Work}

Telecommuting is often considered the context or environment in which an individual's work is carried out, and not an aspect of the work itself. The assumption seems to be that the same work will be done in the same way at home facilitated by ICT as in the office, but with less interruption (Westfall 2004). During telecommuting, the type and characteristics of the ICT artifacts are crucial to defining the context of work and its impacts on telecommuting work outcomes. In the context of telecommuting, use of ICTs can be both an enabler and a constraint to facilitating desirable work outcomes at several levels of analysis in organizations. So, even though the setting where the work takes place is different, as well as methods of accessing information and interacting with colleagues, little research has examined how work is actually taking place (Orlikowski and Barley 2001). Fortunately, recent research is moving in this direction. Golden (2007) collects data from non-telecommuters to understand the implications of

telecommuting on work performance throughout the workplace, not just on individuals. In one of the few studies that begins to address the integration of a particular technology into the work process, findings from Towers et al. (2006) as well as Kakihara (2004) suggest that the use of mobile technology enables flexibility of timing and location of work, and makes it easier to accommodate work and family but also increases expectations of both spheres, leading to greater workload. Others identify both enablers and barriers to mobile work. Importantly, mobile work can be hampered by existing business processes (Brodt and Verburg 2007) and mobile workers need to be creative in developing their work spaces (Hislop and Axtell 2009). For certain jobs, however, mobility may allow both individual and organizational needs to be met (Kakihara and Sørensen 2004). Employing mobile phones to support foreign exchange trading proved to be more usable than a fixed computer, at home or in more traditional locations, for the actual work 
activities as well as personal needs of traders in a Middle Eastern bank (Sørensen and Al-Taitoon 2008).

In reality, the act of telecommuting may enable new and evolving conditions on the nature of the work itself that must be taken into account. As others have pointed out, "Under a new conceptualization, telework [telecommuting] might come to be seen as one of many mechanisms individuals enact to cope with the demands of the modern workplace” (Bailey and Kurland 2002).

\subsection{Telecommuting as a Time-dependent Concept}

An important issue in telecommuting research is the amount of time spent telecommuting (Bélanger et al. 2001; McCloskey and Igbaria 1998; Ramsower 1985) as telecommuters’ experiences with telecommuting will impact their attitudes towards this work arrangement and subsequent outcomes, although it is not often explicitly identified in most studies. The passing of time can affect productivity and adoption of telecommuting by individuals. For example, initially a worker may experience the flexibility enabled by telecommuting as a positive experience. Yet, challenges may surface over time, e.g., the inability to get timely feedback from people, or difficulties working with technology, that may reduce the worker's propensity to telecommute and lower her satisfaction with telecommuting.

The frequency of telecommuting also appears to influence satisfaction with telecommuting. While many studies acknowledge variation in frequency, e.g., number of days per week, few have investigated the influence on outcomes. In one of the few studies to examine this question, Golden and Viega (2005) found a curvilinear U-shaped relationship between the frequency of telecommuting per week and job satisfaction. The relationship was moderated negatively by increased task interdependence and positively by low levels of job discretion. The 
researchers suggest certain jobs may become more difficult to perform when frequency of telecommuting is increased.

Many theories offer "snapshots", focusing on a one-time experience with no accounting for the compounding effects over time. Few researchers have taken this issue into account, although some, e.g., Cousins and Robey (2005), Scheitzer and Duxbury (2006), Bélanger and Allport (2008), did collect data from telecommuters at two points in time. Time can be investigated from a diachronic perspective, i.e., across different periods, or from a synchronic perspective, i.e., within one period. Both are important in the telecommuting context. Recent studies have begun to investigate changing temporal patterns of work when telecommuting (Araújo 2008; Towers et al. 2006).

Even though there are few studies acknowledging this, the effect of time on telecommuting is central to understanding the implications of such work arrangements since time is required for most effects to occur within or across levels of analysis. For example, the impacts of telecommuting on a team may not be observed until individual team members have already experienced telecommuting over time. Alternatively, different individuals on the team may have different temporal patterns of work that may have to be reconciled. For that reason, a telecommuting conceptual model should take into account compounding effects of telecommuting over time to explore conflicting findings (Brodt and Verburg 2007).

\subsection{Telecommuting as a Multi-level Concept}

Telecommuting research often fails to recognize multiple levels of analysis. Yet, outcomes for telecommuters have effect on and are affected by their co-workers', managers', teams’ and subordinates’ outcomes (Pearlson and Saunders 2010). Consequently, researchers should investigate the multiple levels of effects of telecommuting (Perez et al. 2004). For 
example, telecommuting arrangements are commonly expected to motivate employees and reduce organizational costs while improving individual and organizational productivity (Bailey and Kurland 2002; Leonard 2000). Yet, most prior research has been conducted at either the individual or organizational level of analysis (Bailey and Kurland 2002). We found few examples of studies considering these multiple effects concurrently. Some studies do measure factors at the individual level but make inferences at the organizational level (Cousins and Robey 2005). Other studies implicitly recognize the multi-level nature of telecommuting in general (Jarvenpaa and Lang 2005) or its multi-level outcomes (e.g., Sanchez et al (2008); Whittle \& Mueller (2009)). However, most organizational and group level outcomes studied in telecommuting research tend to be simple aggregations of individual-level telecommuting experiences (Pinsonneault and Boisvert 2001). The emphasis on the individual in previous research is perhaps not surprising as the phenomenon of telecommuting challenges our understanding of an organization. Since the industrial age, a core tenant of the business organization has been the separation of the individual's home from the workplace. Thus, much research has been concerned with the impact of this major change on the individual (Orlikowski and Barley 2001).

Another interesting aspect that is rarely studied in relation to telecommuting is the group as a level of analysis, even though research is needed at that level (Bailey and Kurland 2002). Some studies examine telecommuters' relationships with co-workers and find changes in communication patterns among group members (Bélanger and Allport 2008) or negative impacts on co-worker relationships with increased levels of telecommuting (Gajendran and Harrison 2007; Golden 2007). No telecommuting studies, however, seem to focus specifically on the group level of analysis. It is not clear why there has been so little such research. It may be that 
initial research on telecommuting in the USA was in the transportation field, where emphasis was on individual travel patterns and environmental impacts of telecommuting. Yet, virtual teams are increasingly important in organizations, and employees are almost always members of at least one, and often, multiple teams (Bélanger and Watson-Manheim 2006). Some research areas do focus on groups in distributed settings: CSCW (Computer Supported Cooperative Work) and virtual teams. Yet, both CSCW and virtual team literatures do not specifically address telecommuting contexts, and are often more relevant to within-organization groups. Additionally, CSCW research often focuses on the technology itself, such as interfaces for distributed work. Virtual teams literature has not focused on the location of individual in general or telecommuting in particular; researchers have primarily investigated antecedents and emergent processes influencing team effectiveness (e.g., review by Mortensen et al., (2009)).

The lack of emphasis on groups in telecommuting literature may have obscured some important telecommuting relationships. For example, what might be the consequences for group performance if one member is at home? Alternatively, what might be the consequences to companies if individuals in several groups are simultaneously working remotely? In highly distributed companies, the consequences may be different than in more traditional firms where most employees are at the same site. Often, employees have different levels of telecommunication access from home, potentially affecting the performance of the overall group. For example, some groupware degrades to the lowest network characteristic or speed. In other words, in a group where one employee is on a poor connection, it will have negative effects on the entire group's access speed. While this represents only one example, it is clear that the lack of emphasis on group level effects of telecommuting may obscure the existence of compounding effects of individual factors on work outcomes across levels of analysis in an organization. 
A few studies have examined firm-level consequences. Sanchez et al. (2008) found that access to Human Resource commitment practices leads to increased intensity of telework adoption, which is positively related to firm performance. Sanchez et al. (2007) found that firm performance is positively related to the existence of teleworking programs. In a study with respondents spread across 75 countries, Hill et al. (2010) found that workplace flexibility is beneficial to individuals (due to decreased work-life conflict) and to firms (increased capacity for longer work hours).

In summary, there are potential consequences to drawing telecommuting research conclusions without considering multi-level factors. For example, in considering multi-level issues in telecommuting, there is the potential of misaligned incentives across levels. Employees may be rewarded for individual performance but expected to be available as a "team player" by their manager, which also may be an important factor affecting promotion.

\subsection{Summary}

The review of the telecommuting literature reveals several conceptualization issues that are implied but not typically considered by researchers, and highlights the lack of theoretical foundations in this domain. The next section therefore addresses the call for increased use of established organizational theory to guide future research and explain past paradoxes (Bailey and Kurland (2003)) by proposing a multi-level conceptual model of telecommuting.

\section{A MULTI-LEVEL SOCIO-TECHNICAL SYSTEMS TELECOMMUTING \\ FRAMEWORK}

Socio-Technical Systems (STS) theory is used to guide the development of the multilevel framework. STS is first utilized to define and integrate different aspects of telecommuting specific to the telecommuters' personnel subsystem, technical subsystem, and organizational 
structure. It is also used to explicitly identify and account for the effects of both time and multilevel factors that impact telecommuting work systems.

\subsection{Socio-technical Systems (STS) Theory}

STS theory has its roots in the socio-technical systems view of organizations (Katz and Kahn 1966; Trist and Bamforth 1951). The theory has evolved through time as it has been used and tested by researchers from various fields (e.g., Hendrick and Kleiner 2001; Holden and Karsh 2009; Markham 1988). Socio-technical Systems Theory (STS) views organizations as open work systems that transform inputs to desired outputs (Hendrick and Kleiner 2002; Morrison et al. 2005; Pasmore 1988; Trist and Bamforth 1951). A work system consists of two or more persons interacting using some form of job design, hardware and/or software machine(s) or tool(s), and information/knowledge within structure or process(es) in both internal and external environments. Work systems and organizations are considered open in that their boundaries are permeable, allowing interactions with their environment across levels of analysis (Katz and Kahn 1966). Thus, a socio-technical system can be as simple as a person performing a task with a simple tool or as complex as a large number of individuals in a multi-national enterprise working together using advanced ICT. Examples of applications of STS in the IS literature include investigations of IT investment-decision processes (Ryan and Harrison 2000) and user acceptance of ERP systems (Lim et al. 2005).

STS theory incorporates factors from four elements critical to transforming work system inputs to outputs: technology-related factors included in the technical subsystem, social and people-related factors included in the personnel subsystem, organizational structures and work processes included in the organizational structure or work/job design subsystem, and the 
environment external to the work system. These subsystems characterize the internal and external contexts in which people perform their work, as shown in Figure 1.

[Figure 1]

The technical subsystem includes factors representing technologies, policies, and practices that describe the modes of production (e.g., the type and level of ICT support for the work), the actions individuals take on an object when performing work (e.g., the tasks themselves), the strategy for reducing uncertainty in the process (e.g., policies or practices whether supported by ICT or not), the degree of process/workflow integration (e.g., the degree of automation or workflow rigidity), etc. (e.g., Brown 2002). Related to telecommuting, the technical subsystem describes such factors as the types of ICT used when telecommuting, the facilities available to telecommute from, the reward and compensation plans of the organization, task/work design when telecommuting, etc.

The personnel subsystem includes at least three types of factors: demographic characteristics of the workforce, psychosocial aspects of the workforce (e.g., dimensions of personality, attitudes toward the work environment or the work itself, individual motivations, etc.), and the degree of professionalism required to perform the work (e.g., values, norms, or expected behaviour patterns of the job, team, and/or organization). Outcomes of the personnel subsystem primarily describe the way tasks are performed. Related to telecommuting, factors that are considered part of the personnel subsystem can include workers' motivations to telecommute, attitudes toward the work while telecommuting, beliefs or expectations for reward, compensation, and/or communication when telecommuting, personality preferences for working alone or in collaboration with others, telecommuter work/life balance issues, and telecommuter demographics. 
The organizational structure subsystem is typically characterized in terms of centralization, formalization, and complexity. Centralization refers to the level and degree of formal decision-making in a work system (e.g., strategic, tactical, or operational). Formalization refers to the degree to which jobs or tasks with a work system are standardized. There are two types of complexity assessed in relation to the STS work system: differentiation and integration. Differentiation complexity takes three forms - vertical, horizontal, or spatial - and refers to the degree to which a work system or organization is segmented into parts. Integration complexity refers to the type and number of mechanisms that are required in the work system to ensure communication, collaboration, and control of the differentiated elements in a work system. In general, the need for integrating mechanisms goes up as the degree of differentiation increases. Related to telecommuting, the organizational structure subsystem characterizes such aspects of the work system describing the number and degree of differentiation complexity existing in the organization when telecommuting, the degree to which work tasks are standardized or ad hoc (formalization) when telecommuting, and the location and degree of formal decision-making in the work system, (centralization) when telecommuting.

The work environment describes the relevant characteristics of the context within which the work system operates (both internal and external at whatever level of analysis). It is critical that work systems and organizations be able to adapt to relevant factors in their environment. Environmental factors that positively or negatively affect work systems in organizations can be socioeconomic, educational, political, cultural, or legal. For each organization and work system, these factors will differ in type, quality, and importance. For example, the external environment of the telecommuting work system may describe the political climate in relation to stakeholders external to the telecommuting work system being analyzed, the regional or national culture in 
relation to trust and work, the work-group, team, or organizational traditions for collaborating face-to-face vs. virtually, and the legal requirements for transacting business, protecting proprietary information, or providing secure ICT infrastructure when telecommuting. These subsystems continually and jointly interact with each other and both internal and external organizational environments to produce work system outcomes and organizational survival (DeGreene 1973; Hendrick and Kleiner 2002; Pasmore 1988; Trist and Bamforth 1951). For the purposes of developing the multilevel telecommuting framework, we focus on the internal subsystem environments (personnel, technical, structure) and limit our discussion of environmental conditions external to the organization. STS suggests that there is interaction between the subsystems. For example, the technical subsystem and organizational structure conjointly affect the process of transforming antecedent inputs to outputs. In reality, the three internal subsystems operate under the principle of joint causation, meaning they are affected by other causal events in the telecommuting environment (Hendrick 2002; Katz and Kahn 1966). This principle of joint causation leads to the STS concept of the joint optimization of a work system.

Joint optimization refers to the potential or ability of work systems to accomplish their intended transformative process(es). Typically, once designed, the technical subsystem is relatively stable, and therefore, it is often left to the personnel subsystem to adapt to the organizational structure and external environment. For example, when telecommuting, workers may have to continuously interact with the ICTs and with the organizational structure (e.g. team coordination), when performing tasks and producing outcomes. Consequently, the way telecommuters perform their tasks may be significantly altered over time when compared to workers who perform the same tasks but are not telecommuting. Thus, we argue that 
interactions between the telecommuting personnel, technical, and organizational structure subsystems result in outcomes for telecommuters at the multiple levels of analysis. Outcomes at the group and organizational levels of analysis either emerge or are realized from the aggregation of individual level telecommuting outcomes.

In our framework, we use the concepts of joint causation and joint optimization to highlight feedback that exists over time and across levels of analysis as the work system seeks to reach stability or steady state. The principles of joint causation and joint optimization can be represented and operationalized with the concept of fit (Venkatraman 1989). For example, in information systems, fit has been used to study the impact of task-technology fit on outcomes (Goodhue and Thompson 1995; Vessey and Galletta 1991). Contingency theory researchers use the concept of fit to look at the inter-relationships of constructs and their impacts on various variables. Related to telecommuting, in a generic model of outcomes in distributed work arrangements, Bélanger and Collins (1998) used Venkatraman's conceptualization of fit as gestalt to consider the internal coherence between a large number of attributes (e.g., individual, organizational, work, and technology characteristics) whose interactions could not be precisely formulated. In the development of our multi-level STS telecommuting framework, we propose that fit represents the interaction between the STS subsystems and their environment across levels of analysis.

\subsection{A Multi-Level Telecommuting Framework}

STS theory can be used to theorize and analyze how multiple factors jointly influence telecommuter work outcomes and worker motivations to telecommute over time. Additionally, it can be used to conceptualize how telecommuting results in multi-level outcomes by jointly impacting individual, group, and organizational level socio-technical factors - such as 
individual-level satisfaction/dissatisfaction, team-level productivity, and organizational-level absenteeism.

As discussed earlier, consequences of telecommuting at the group and organizational level have been under researched as compared to the individual-level. As interdependent tasks have become more spatially distributed, the need to understand the group-level implications becomes more important. Recent research indicates that the configuration of the work group may influence communication patterns and ultimately performance (O’Leary and Mortensen forthcoming). The implication of different configurations, e.g., one isolated person as compared to multiple isolated people, is just one area of group level analysis that could be explored. In addition, many firms approach telecommuting from a strategic perspective, but little research has addressed organizational-level implications. We propose to address these limitations with the Multi-Level Telecommuting Framework presented in Figure 2, which is further described below.

The framework depicts high-level relationships between the theoretical constructs of the telecommuting environment. In the framework, dashed lines portray the individual, group, and organizational levels of analysis and represent the permeability of these components across levels of analysis. In most complex organizational settings (a.k.a., the real world), the telecommuting work environment is an amalgam of individual, group and organizational contexts. Each individual telecommuter will therefore experience this combination of contexts differently. Conceptually, however, the telecommuting subsystems should be depicted as existing at different levels of analysis (Hendrick and Kleiner 2001; Klein et al. 1994; Rousseau 1985). In the model, subsystems are shown as interconnected, illustrating the principles of joint causation with outcomes depicted at the individual, group, and organizational levels of analysis. [Figure 2] 
At all levels of analysis, the framework specifies telecommuting personnel, technical, and organizational structure subsystems that result in telecommuting work outcomes. Outcomes of telecommuting propensities, motivations, behaviours, processes, and structures at the individual level of analysis impact outcomes across levels of analysis. The same is true about the outcomes of telecommuting propensities, behaviours, processes, and structures at other levels of analyses. These outcomes, over time, will affect the multi-level socio-technical system factors that impact future multi-level telecommuting behaviours and outcomes.

The framework can help researchers distinguish multi-level antecedents and outcomes of telework to identify areas of importance to be investigated and identify gaps where significant topics are not being addressed. In Table 3, we illustrate the use of the internal subsystems of STS to show how antecedents and outcomes can differ across multiple levels of analysis in telecommuting. For example, when investigating the performance of work activities by telecommuters, the framework helps differentiate antecedents of performance at the individuallevel from the group and organizational levels, and it also makes clear that outcomes at the individual-level will only partially explain overall performance implications. [Table 3]

\section{ILLUSTRATING THE MULTI-LEVEL TELECOMMUTING FRAMEWORK}

An example of the applicability of the multilevel telecommuting framework can be derived from data we collected to understand communication patterns and media choices in work groups with distributed team members. Practitioner data was collected from two, Fortune 100 high tech ICT sales organizations where employees were given the option to telecommute. Data 
from these organizations was collected using semi-structured interviews. For detailed explanations see (omitted for anonymity in review).

\subsection{Firm A}

Firm A has a culture that relies heavily on email communication, and has a loose organizational structure with sales people and technical workers interfacing on multiple virtual project teams. There is a general lack of clarity in roles and responsibilities on these virtual teams. Workers depend on their social networks to know who, where, and how to access necessary information and to share knowledge. The amount of relationship development (referring to the personnel subsystem) varies widely depending on what project a worker is involved in at the time. The structural subsystem includes high task interdependence due to individuals working on multiple project teams. Thus, the number of meetings and the project management processes vary widely. Training on general company issues is provided, but little training exists for how workers can best access information and share while telecommuting (technical subsystem). Few workers possess permanent offices. Instead, hotelling facilities are set up in remote locations where workers can schedule an office or work from home (resource environment). At the organizational level, the online employee directory and Firm A's intranet are reported as good sources of general information. Also, the variety of ICT options and support are reported as positive motivators at the group and organization level.

Despite organizational support for telecommuting, workers in Firm A report a general lack of desire and frustration with this arrangement. Employees complain that the formal training received was not useful. Telecommuting was also reported to result in poor information gathering, lack of knowledge sharing, and little social network development. There was a perceived lack of training at the group and organization levels on how to access and share 
information effectively. At the group level, lack of interaction with peers resulted in limited knowledge sharing within groups, and difficulty in finding and talking to people when needed sometimes resulted in inefficient teamwork. At the individual level, most issues stemmed from individuals' lack of ability to develop relationships and be "plugged in" to the network so that they could do their work effectively and efficiently. Working remotely is perceived to create barriers to building social networks needed to get the work done. In addition, a perceived lack of clarity of roles and responsibilities in groups is reported to make work more difficult. Finally, there were positive outcomes for individuals in Firm A. Workers enjoyed the flexibility to work at home and reduced travel distances and costs.

Firm A illustrates the impacts that organizational, group, and individual level factors can have on individual workers choosing to telecommute, as shown in Figure 3. This organization illustrates that the real barrier to telecommuting in Firm A is the lack of ability to build knowledge and social networks that allow workers to access and share information in this highly task interdependent environment. This effect occurs over time as individuals realize how difficult it is to develop their networks of experts when they are not physically in the office. The overall result is that, although telecommuting is supported by the culture and ICT, Firm A workers generally preferred not to telecommute.

[Figure 3]

\subsection{Firm B}

Firm B sells total ICT solutions to primarily one client. Therefore, many of the sales and technical workers' offices are located at the client's location. Firm B is organized around an embedded matrix structure. Telecommuting was implemented in Firm B with the goal of decreasing costs and providing better service to the client. Yet, the culture at Firm B emphasizes 
customer satisfaction and spending face time with the customer. This results in a misalignment of telecommuting and reward and compensation plans.

Sales and technical employees are expected to look for opportunities to sell the customer on new ICT solutions while working on existing projects. Selection and promotion in Firm B is based on "visibility and who you know." For the structural subsystem, workers are assigned to multiple projects and managers negotiate to get people they know assigned to their projects. Firm B’s reward and compensation strategies for most sales and technical personnel are based on a split percentage (e.g. 65/35, 80/20, etc.) between a base salary and revenue generation (based on customer satisfaction and sales quotas). The worker, in yearly review meetings with his superior, chooses this percentage. Account managers are given a base salary, but bonuses are based entirely on customer satisfaction. The technical subsystem provides workers with reimbursement for an extra phone line at home. Management control is primarily based on faceto-face meetings and organizational communication is heavily reliant on email and face-to-face meetings.

At the individual level, sales personnel report satisfaction with Firm B’s reward \& compensation plan (it is possible to earn up to $150 \%$ of their base salary), while most technical personnel are dissatisfied with the plan. However, at the organization level, Firm B's reward \& compensation plan reinforces existing functional silos and discourages groups from working together. Individual access to necessary information from remote locations is restricted due to organizational level security concerns. Therefore, workers cannot access many files they need to work from home or remote locations. Some ICT applications are available to facilitate project approvals but are not user friendly. These applications reportedly take too long to access information, schedule meetings, and are difficult to operate because they are "over engineered.” 
At the group level, workers feel pressure from managers to be in front of the client or in face-to-face group meetings (even if these meetings are spontaneously called and ICT is available), which greatly discourages telecommuting. Further, group morale is reported as being low due to a lack of social interaction, and a general perception that a lack of visibility make it difficult to get on good projects, get to know key people in the organization, and ultimately to get promoted. As one person pointed out, "it’s hard to stand out in an email crowd.” Workers also report difficulties understanding common group goals when working away from the office. Finally, telecommuters report there is not enough time to do all the tasks assigned to them. Many reported feelings of isolation and a lack of connection to the organization and co-workers since choosing to telecommute. Time plays a vital role as individuals experience increased frustration with the work environment and with their group interactions as they try working remotely. Eventually, they conclude that they have to be physically present to be able to function in the organization.

Figure 4 illustrates the compounding, cross-level impacts of telecommuting in Firm B caused by misaligned organizational culture, management practices, and reward \& compensation for telecommuters. In Firm B, telecommuting was implemented to improve customer and worker satisfaction and increase organizational performance and sales. However, reward, promotion, and compensation norms of the company based on face-to-face interaction (i.e., professionalism factors in the personnel subsystem) and security measures prevented workers from accessing necessary information when telecommuting (i.e., factors associated with the technical subsystem and external environment of the telecommuting work system). As a result, few people chose to telecommute and morale plummeted among the workforce.

[Figure 4] 


\section{IMPLICATIONS AND CONTRIBUTIONS}

The multilevel telecommuting framework offers possibilities of conceptualizations to address prior issues identified in the literature, including the need to account for time (through feedback loops), to account for telecommuting being embedded in work practices (through the STS subsystems), and to account for telecommuting being a multi-level concept.

The telecommuting framework has important implications for research and practice. First, the varied and often conflicting findings in prior literature with respect to the effects of telecommuting on work outcomes (e.g., better technology leads to better productivity) can potentially be explained by introducing multiple levels of analysis and the effect of time on telecommuting. Impacts of telecommuting factors across levels of analysis are inherent and of vital importance in organizational research (Rousseau 1985), but multi-level issues have not been expressly considered in telecommuting research (Bailey and Kurland 2002; Pearlson and Saunders 2001). Examples of research questions this framework can help address include: Do the factors in the telecommuting work environment that affect individual telecommuters also affect virtual teams? What are the characteristics of ICT artefacts at different levels of analysis that affect telecommuting behaviours and work outcomes?

It is also possible for individual, group, and organizational level motivators to be in conflict with each other, affecting the decision to telecommute and making it difficult for practitioners and academics to understand ultimate outcomes of telecommuting. For example, an individual may want to work at home to increase productivity by reducing interruptions. At the same time, he may experience group-level incentives to collaborate with co-workers, creating a “distance” with colleagues. Thus, telecommuters may experience individual satisfaction with telecommuting while at the group level there may be negative impacts on member relationships, 
which may ultimately lead to reduced performance. Therefore, it is recommended that future investigations by both academics and practitioners consider the multi-level nature of telecommuting when exploring its various impacts.

Another key contribution is how the framework stresses the importance of looking at the passing of time in studies of telecommuting. In prior literature, few, if any, studies have attempted to address the compounding effects of telecommuting over time, which the proposed theoretical framework takes into consideration It suggests that outcomes will not be static but change as the experiences of each telecommuter change. Moreover, telecommuting behaviours and work outcomes at one point in time are expected to be influenced by past experiences and in turn affect future telecommuting experiences. Potential research questions include: How do telecommuting work outcomes change over time when workers telecommute? Do telecommuters report the same satisfaction and dissatisfaction after a single experience with telecommuting as they do after several months? How do properties of telecommuting ICT artefacts impact future telecommuting behaviors and work outcomes? Over time, what are the adjustments to their work environments that organizations need to make after implementing telecommuting to improve work outcomes? Only a truly longitudinal study could attempt to evaluate these effects, and it is recommended that such studies should be conducted in the future.

Finally, the framework shifts telecommuting from the static context in which the work is carried out to an embedded aspect of the work itself. For example, investigating the implications of changes in communication patterns (e.g., as found by Belanger and Allport, 2008), and new forms of connectivity that are likely to emerge over time, becomes more salient under this framework. These changes may have profound implications for organizations, which are not likely to emerge when telecommuting is treated simply as a work setting. 
In addition to the recommendations above, several avenues for future research can be explored with the framework. First and foremost, the theoretical framework needs to be tested in a variety of telecommuting environments. A first step might be to evaluate the explanatory power of the framework with data collected over time, from more than one organization, across levels of analysis, and analyzed and integrated using the framework to allow comparisons. Additional research can also explore other forms of technology-mediated work for which the framework could apply. For example, how can the framework help explain findings related to flextime? Do organizations with mandatory telecommuting policies exhibit similar antecedents and consequences as organizations that allow individuals the choice to telecommute? The framework can provide a lens to look at these and other research questions in the distributed work domain. Finally, the framework could be extended according to STS to include the external environment. Such an extension could help explore legal, cultural, or political impacts of telecommuting on organizations, groups, and individuals.

\section{CONCLUSION}

Building on Socio-Technical Systems theory, a multi-level telecommuting framework was developed, which proposes theoretical relationships that address the conceptualization issues found in telecommuting research: namely, (1) telecommuting and its ICT artefacts as the context or environment in which work is performed instead of just as an aspect of the actual work itself; (2) telecommuting as a multi-level concept whose impacts are often realized at the individual level of analysis but also have influences and outcomes across levels of analysis; and, (3) telecommuting as a concept whose antecedents and outcomes have effects over time. The theoretical framework can be used as a lens for evaluating past telecommuting research, and developing new areas of inquiries in telecommuting. 


\section{REFERENCES}

Ahuja, M.K., and Galvin, J.E. 2003. "Socialization in virtual groups," Journal of Management (29:2), pp 161-185.

Araújo, E.R. 2008. "Technology, Gender and Time: A Contribution to the Debate," Gender, Work and Organization (15:5), pp 477-503.

Axtell, C., Hislop, D., and Whittaker, S. 2008. "Mobile technologies in mobile spaces: Findings from the context of train travel," International Journal of Human-Computer Studies (66:12), pp 902-915.

Bailey, D.E., and Kurland, N.B. 2002. "A review of telework research: Findings, new directions, and lessons for the study of modern work," Journal of Organizational Behavior (23:4), Jun, p 383.

Baker, E., Avery, G.C., and Crawford, J. 2006. "Home Alone: The Role of Technology in Telecommuting," Information Resources Management Journal (19:4), pp 1-22.

Bélanger, F. 1999. "Worker's Propensity to Telecommute: An Empirical Study," Information and Management (35), pp 139-153.

Bélanger, F., and Allport, C. 2008. "Collaborative Technologies in Knowledge Telework: An Exploratory Study," Information Systems Journal (18:1), pp 101-121.

Bélanger, F., Collins, R., and Cheney, P.H. 2001. "Technology Requirements and Work Group Communication for Telecommuters," Information Systems Research (12:2), June, pp 155-176.

Bélanger, F., and Collins, R.W. 1998. "Distributed Work Arrangements: A Research Framework," The Information Society: An International Journal (14:2), May 1, pp 137152(116).

Bélanger, F., and Watson-Manheim, M.B. 2006. "Virtual Teams And Multiple Media: Structuring Media Use To Attain Strategic Goals," Group Decision and Negotiations (15:4), pp 299-321.

Bélanger, F., Watson-Manheim, M.B., and Jordan, D.H. 2002. "Aligning IS Research and Practice: A Research Agenda for Virtual Work," Information Resources Management Journal (15:3), Jul-Sep, p 48.

Brodt, T.L., and Verburg, R.M. 2007. "Managing mobile work-insights from European practice," New Technology, Work \& Employment (22:1), pp 52-65.

Brown, O., Jr. 2002. "Macroergonomics Methods: Participation," in: Macroergonomics: theory, methods, and applications, H.W. Hendrick and B.M. Kleiner (eds.). Mahwah, N.J.: Lawrence Erlbaum Associates, pp. xi, 412.

Chudoba, K., Watson-Manheim, M.B., Crowston, K., and Lee, C.S. 2011 "ICT-Supported Meetings in Practice," Journal of Organizational and End User Computing (23:2), AprilJune, $p$ In press.

Cousins, K.C., and Robey, D. 2005. "Human agency in a wireless world: Patterns of technology use in nomadic computing environments," Information and Organization (15:2), pp 151180.

DeGreene, K.B. 1973. Sociotechnical systems. Englewood Cliffs, NJ: Prentice-Hall.

Desrochers, S., Hilton, J.M., and Larwood, L. 2005. "Preliminary validation of the work-family integration-blurring scale," Journal of Family Issues (26:4), May, pp 442-466.

Duxbury, L., and Neufeld, D. 1999. "An empirical evaluation of the impacts of telecommuting on intra-organizational communication," Journal of Engineering and Technology Management (16:1), Mar, p 1.

Gajendran, R.S., and Harrison, D.A. 2007. "The good, the bad, and the unknown about telecommuting: Meta-analysis of psychological mediators and individual consequences," Journal of Applied Psychology (92:6), pp 1524 - 1541. 
Golden, T. 2006. "The Role Of Relationships In Understanding Telecommuter Satisfaction," Journal Of Organizational Behavior (27), pp 319-340.

Golden, T., and Viega, J.F. 2005. "The Impact of Extent of Telecommuting on Job Satisfaction: Resolving Inconsistent Findings," Journal of Management (31:2), April, pp 301-318.

Golden, T.D. 2007. "Co-workers who telework and the impact on those in the office: Understanding the implications of virtual work for co-worker satisfaction and turnover intentions," Human Relations (60:11), pp 1641-1667.

Golden, T.D., Veiga, J.F., and N., D.R. 2008. "The impact of professional isolation on teleworker job performance and turnover intentions: Does time spent teleworking, interacting faceto-face, or having access to communication-enhancing technology matter? ," Journal of Applied Psychology (93:6), pp 1412 -1421.

Goodhue, D.L., and Thompson, R.L. 1995. "Task-Technology Fit and Individual Performance," MIS Quarterly (19:2), pp 213-235.

Hartig, T., Kylin, C., and Johansson, G. 2007. "The Telework Tradeoff: Stress Mitigation vs. Constrained Restoration," Applied Psychology (56:2), pp 231 - 253.

Hendrick, H.W. 2002. "An overview of macroergonomics," in: Macroergonomics: theory, methods, and applications, H.W. Hendrick and B.M. Kleiner (eds.). Mahwah, N.J.: Lawrence Erlbaum Associates, pp. xi, 412.

Hendrick, H.W., and Kleiner, B.M. 2001. Macroergonomics: An Introduction to Work System Design. Santa Monica, CA: Human Factors and Ergonomics Society.

Hendrick, H.W., and Kleiner, B.M. (eds.). 2002. Macroergonomics: Theory, Methods, and Applications. Mahwah, N.J.: Lawrence Erlbaum Associates.

Hill, E.J., Erickson, J.J., Holmes, E.K., and Ferris, M. 2010. "Workplace Flexibility, Work Hours, and Work-Life Conflict: Finding an Extra Day or Two," Journal of Family Psychology (24:3), Jun, pp 349-358.

Hislop, D., and Axtell, C. 2009. "To infinity and beyond?: workspace and the multi-location worker," New Technology, Work \& Employment (24:1), pp 60-75.

Holden, R.J., and Karsh, B. 2009. "A theoretical model of health information technology usage behaviour with implications for patient safety," Behaviour \& Information Technology (28:1), January-February, pp 21-38

Hornung, S., Rousseau, D.M., and Glaser, J. 2009. "Why supervisors make idiosyncratic deals: antecedents and outcomes of i-deals from a managerial perspective," Journal of Managerial Psychology (24:7-8), pp 738-764.

Hunton, J.E., and Norman, C.S. 2010. "The Impact of Alternative Telework Arrangements on Organizational Commitment: Insights from a Longitudinal Field Experiment," Journal of Information Systems (24:1), pp 67-90

Igbaria, M. 1999. "The Driving Forces in the Virtual Society," Communications of the ACM (42:12), DEC, pp 64-70.

Jarvenpaa, S.L., and Lang, K.R. 2005. "MANAGING THE PARADOXES OF MOBILE TECHNOLOGY," Information Systems Management (22:4), Fall2005, pp 7-23.

Joli, B. 2009. "Telecommuting Trends in the 2009 Economy." Bright Hub, from http://www.brighthub.com/office/home/articles/22829.aspx

Kakihara, M., and Sørensen, C. 2004. "Practicing Mobile Professional Work: Tales of Locational, Operational, and Interactional Mobility," The Journal of Policy, Regulation and Strategy for Telecommunication, Information and Media (6:3), pp 180-187.

Katz, D., and Kahn, R.L. 1966. "Common characteristics of open systems," in: The social psychology of organizations, D. Katz and R.L. Kahn (eds.). New York,: Wiley, pp. 14-29. 
Khalifa, M., and Davison, R.M. 2008. "Explaining the intended continuance level of telecommuting," International Journal of Internet and Enterprise Management (5:3), pp $264-294$.

Klein, K.J., Dansereau, F., and Hall, R.J. 1994. "Level Issues in Theory Development, Data Collection, and Analysis," Academy of Management Review (19:2), pp 195-229.

Kuldeep, K., van Fenema, P.C., and Glinow, M.A. 2009. "Offshoring and the global distribution of work: Implications for task interdependence theory and practice," Journal of International Business Studies (40), pp 642 - 667.

Lee, H.G., B., S., and Higa, K. 2007. "Telework vs. central work: A comparative view of knowledge accessibility," Decision Support Systems (43:3), p 687.

Leonard, B. 2000. "Telework Has Many Advantages," in: HRMagazine. pp. 23-24.

Lim, E.T.K., Pan, S.L., and Tan, C.W. 2005. "Managing user acceptance towards enterprise resource planning (ERP) systems - understanding the dissonance between user expectations and managerial policies," European Journal of Information Systems (14:2), Jun, pp 135-149.

Madsen, S.R. 2006. "Work and Family Conflict: Can Home-Based Teleworking Make a Difference?," International Journal of Organization Theory and Behavior (9:3), pp 307350.

Markham, S.E. 1988. "Pay-for-Performance Dilemma Revisited: Empirical Example of the Importance of Group Effects," Journal of Applied Psychology (73:2), pp 172-180.

Mayo, M., Pastor, J.C., Gomez-Mejia, L., and Cruz, C. 2009. "Why Some Firms Adopt Telecommuting While Others Do Not: A Contingency Perspective," Human Resource Management (48:6), Nov-Dec, pp 917-939.

Mazmanian, M.A., Orlikowski, W.J., and Yates, J. 2005. "Crackberries: The Social Implications of Ubiquitous Wireless E-Mail Devices," in: Designing Ubiquitous Information Environments: Socio-technical Issues and Challenges, C. Sørensen, Yoo, Y., Lyytinen, K., DeGross, J.I. (ed.). New York: Springer, pp. 337-343.

McCloskey, D.W., and Igbaria, M. 1998. "A Review of the Empirical Research on Telecommuting and Directions for Future Research," in: The Virtual Workplace, M. Igbaria and M. Tan (eds.). Hershey: Idea Group Pub., pp. 338-358.

Morrison, D., Cordery, J., Girardi, A., and Payne, R. 2005. "Job design, opportunities for skill utilization, and intrinsic job satisfaction," European Journal of Work and Organizational Psychology (14:1), Mar, pp 59-79.

Mortensen, M., Caya, O., and Pinsonneault, A. 2009. "Understanding Virtual Team Performance: A Synthesis of Research on the Effects of Team Design, Emergent Processes, and Emergent States," in: Research Paper No. 4738-09. Cambridge, MA: MIT Sloan School of Management.

O'Neill, T.A., Hambley, L.A., Greidanus, N.S., MacDonnell, R., and Kline, T.J.B. 2009. "Predicting teleworker success: an exploration of personality, motivational, situational, and job characteristics," New Technology, Work \& Employment (24:2), pp 144-162.

O'Leary, M.B., and Mortensen, M. forthcoming. "Go (Con) figure: Subgroups, Imbalance, and Isolates in Geographically Dispersed Teams," Organization Science).

Orlikowski, W., and Barley, S.R. 2001. "Technology and Institutions: What Information Systems Research and Organization Studies Can Learn from Each Other," MIS Quarterly (25), pp 145-165.

Orlikowski, W., and Scott, S. 2008. "Sociomateriality: Challenging the Separation of Technology," Work, and Organization. AoM Annals (2:1), pp 433-474.

Paez, A., and Scott, D.M. 2007. "Social influence on travel behavior: a simulation example of the decision to telecommute," Environment and Planning A (39:3), Mar, pp 647-665. 
Pasmore, W.A. 1988. Designing effective organizations: the sociotechnical systems perspective. New York: Wiley.

Pearce, J.A. 2009. "Successful Corporate Telecommuting with Technology Considerations for Late Adopters," Organizational Dynamics (38:1), Jan-Mar, pp 16-25.

Pearlson, K., and Saunders, C. 2010. Managing and Using Information Systems, (4 ed.). JohnWiley.

Pearlson, K.E., and Saunders, C.S. 2001. "There's No Place Like Home: Managing Telecommuting Paradoxes," Academy of Management Executive (15:2), pp 117-128.

Perez, M.P., Sanchez, A.M.L.C., and Pilar Jimenez, M.J.V. 2004. "A technology acceptance model of innovation adoption: the case of Teleworking," European Journal of Innovation Management (7:4), pp 280-291.

Peters, P., and Heusinkveld, S. 2010. "Institutional explanations for managers' attitudes towards telehomeworking," Human Relations (63:1), Jan, pp 107-135.

Pinsonneault, A., and Boisvert, M. 2001. "The Impacts of Telecommuting on Organizations and Individuals: A Review of the Literature," in: Telecommuting and Virtual Offices: Issues and Opportunities, N.J. Johnson (ed.). London: Idea Group Publishing, pp. 163-185.

Pollster_YouGov_UK. 2007. "SW2000 Telework Studies." Retrieved January 8, 2009, from http://www.noelhodson.com/index files/statistics2006to2008.htm\# Toc229386682

Ramsower, R.M. 1985. Telecommuting: The Organizational and Behavioral Effects of Working at Home. Michigan:

Rousseau, D.M. 1985. "Issues of Level in Organizational Research: Multi-level and Cross-level Perspectives," in: Research in Organizational Behavior. pp. 1-37.

Ryan, S.D., and Harrison, D.A. 2000. "Considering social subsystem costs and benefits in information technology investment decisions: A view from the field on anticipated payoffs," Journal of Management Information Systems (16:4), Spr, pp 11-40.

Sánchez, A.M., Pérez, M.P., Carnicer, P.d.L., and Jiménez, M.J.V. 2007. "Teleworking and workplace flexibility: a study of impact on firm performance," Personnel Review (36:1), pp 42-64.

Sánchez, A.M., Pérez, M.P., Jiménez, M.J.V., and Carnicer, P.d.L. 2008. "Telework adoption, change management, and firm performance," Journal of Organizational Change Management (21:1), pp 7-31.

Schweitzer, L., and Duxbury, L. 2006. "Benchmarking the Use of Telework Arrangements in Canada," Canadian Journal of Administrative Sciences (23:2), Jun, pp 107-109.

Siha, S.M., and Monroe, R.W. 2006. "Telecommuting's past and future: a literature review and research agenda," Business Process Management Journal (12:4), pp 455 - 482.

Smith, R.L.J. 2004. "Work at Home Grows in Past Year by $7.5 \%$ in US." from www.workingfromanyywhere.org/news/pr090204.htm

Sørensen, C., and Al-Taitoon, A. 2008. "Organisational usabilityof mobilecomputing-Volatility and control in mobile foreign exchange trading," International Journal of HumanComputer Studies (66), pp 916-929.

Sørensen, C., Al-Taitoon, A., Kietzmann, J., Pica, D., Wiredu, G., Elaluf-Calderwood, S., Boateng, K., Kakihara, M., and Gibson, D. 2008. "Enterprise Mobility: Lessons from the Field," Information Knowledge Systems Management Journal - Special issue on Enterprise Mobility (7:1 \& 2), pp 243-271.

Towers, I., Duxbury, L., Higgins, C., and Thomas, J. 2006. "Time thieves and space invaders: technology, work and the organization," Journal of Organizational Change Management: Space and Time and Organisation Change (19:5), pp 593-618

Trist, E.L., and Bamforth, K.W. 1951. "Some Social and Psychological Consequences of the Longwall Method of Coal-Getting," Human Relations (4:1), pp 3-38. 
Venkatraman, N. 1989. "The Concept of Fit In Strategy Research: Toward Verbal and Statistical Correspondence," Academy of Management Review (4:3), pp 423-444.

Vessey, I., and Galletta, D. 1991. "Cognitive Fit: An Empirical Study of Information Acquisition," Information Systems Research (2:1), pp 63-84.

Virick, M., DaSilva, N., and Arrington, K. 2010. "Moderators of the curvilinear relation between extent of telecommuting and job and life satisfaction: The role of performance outcome orientation and worker type," Human Relations (63:1), Jan, pp 137-154.

Wajcman, J., Bittman, M., Brown, J. E. 2008. "Families without Borders: Mobile Phones, Connectedness and Work-Home Divisions " Sociology (42:4), pp 635-652.

Ward, N., and Shabha, G. 2001. "Teleworking: An Assessment of Socio-Psychological Factors," Facilities (19:1/2), pp 61-70.

Watson-Manheim, M.B., and Bélanger, F. 2002. "Support for Communication-based Work Processes in Virtual Work," e-Services Quarterly (1:3), Summer, pp 61-82.

Westfall, R. 2004. "Does Telecommuting Really Increase Productivity?" " Communications of the ACM (47:8), August pp 93-96.

Whittle, A., and Mueller, F. 2009. "I could be dead for two weeks and my boss would never know: telework and the politics of representation," Technology, Work and Employment (24:2), pp 131-143.

Workman, M., Kahnweiler, W., and Bommer, W. 2003. "The effects of cognitive style and media richness on commitment to telework and virtual teams," Journal of Vocational Behavior (63:2), Oct, pp 199-219.

WorldatWork. 2009.

"Telework Trendlines 2009." from http://www.worldatwork.org/waw/adimLink?id=31295\&from=presshome 
Table 1. Telecommuting Literature Reviews

\begin{tabular}{|c|c|c|c|c|}
\hline Authors & $\begin{array}{l}\text { Years } \\
\text { Covered }\end{array}$ & Focus of Review & Main Findings & Concerns Raised \\
\hline $\begin{array}{l}\text { Bailey \& } \\
\text { Kurland } \\
\text { (2002) }\end{array}$ & $\begin{array}{l}1984 \text { to } \\
2001\end{array}$ & $\begin{array}{l}\text { Who participates } \\
\text { in telework? } \\
\text { Why they do? } \\
\text { What happens } \\
\text { when they do? }\end{array}$ & $\begin{array}{l}\text { Male professionals and } \\
\text { female clerical workers } \\
\text { predominate. } \\
\text { No clear evidence } \\
\text { telework increases job } \\
\text { satisfaction and } \\
\text { productivity. }\end{array}$ & $\begin{array}{l}\text { Research needs to go } \\
\text { beyond individual } \\
\text { teleworkers. } \\
\text { Research should revisit } \\
\text { why people telecommute. } \\
\text { Research should } \\
\text { emphasize theory- } \\
\text { building using existing } \\
\text { theories. }\end{array}$ \\
\hline $\begin{array}{l}\text { Belanger \& } \\
\text { Collins } \\
(1998)\end{array}$ & $\begin{array}{l}1983- \\
1996\end{array}$ & $\begin{array}{l}\text { Distributed work } \\
\text { arrangements in } \\
\text { general; most } \\
\text { literature is on } \\
\text { telecommuting, } \\
\text { most common } \\
\text { form of such } \\
\text { arrangements }\end{array}$ & $\begin{array}{l}\text { Organizations use } \\
\text { telecommuting to cut } \\
\text { costs and as incentive to } \\
\text { best employees. } \\
\text { Individual, work, } \\
\text { organizational, and } \\
\text { technology variables } \\
\text { must fit to lead to } \\
\text { successful outcomes. }\end{array}$ & $\begin{array}{l}\text { Previous research focuses } \\
\text { on bivariate relationships } \\
\text { only. } \\
\text { No theoretical } \\
\text { underpinnings. } \\
\text { Need more empirical } \\
\text { research. } \\
\text { Little hypothesis-driven } \\
\text { research. }\end{array}$ \\
\hline $\begin{array}{l}\text { McCloskey } \\
\text { \& Igbaria } \\
(1998)\end{array}$ & $\begin{array}{l}1982- \\
1995\end{array}$ & $\begin{array}{l}\text { Review of the } \\
\text { empirical research } \\
\text { for future } \\
\text { directions }\end{array}$ & $\begin{array}{l}\text { Telecommuting research } \\
\text { focused on five areas: } \\
\text { small pilot studies, extent } \\
\text { of telecommuting } \\
\text { participation, beliefs and } \\
\text { perceptions of } \\
\text { telecommuting } \\
\text { (perceived impacts only), } \\
\text { advantages and } \\
\text { disadvantages of } \\
\text { telecommuting, and work } \\
\text { and family issues. }\end{array}$ & $\begin{array}{l}\text { Lack formal definitions } \\
\text { of telecommuting. } \\
\text { Methodological } \\
\text { weaknesses, i.e., small or } \\
\text { poorly constructed } \\
\text { samples, cross-sectional } \\
\text { surveys only. } \\
\text { Lack control of } \\
\text { extraneous variables, } \\
\text { (i.e., employment status, } \\
\text { job type, telecommuting } \\
\text { participation level). }\end{array}$ \\
\hline $\begin{array}{l}\text { Pinsonneault } \\
\text { \& Boisvert } \\
(2001)\end{array}$ & $\begin{array}{l}1983- \\
1999\end{array}$ & $\begin{array}{l}\text { Impacts of } \\
\text { telecommuting on } \\
\text { individuals and } \\
\text { organizations, and } \\
\text { managerial } \\
\text { implications } \\
\end{array}$ & $\begin{array}{l}\text { Schedule flexibility, no } \\
\text { interruptions, and } \\
\text { commute savings as } \\
\text { benefits; professional and } \\
\text { social isolation as } \\
\text { drawbacks. }\end{array}$ & $\begin{array}{l}\text { No particular concerns } \\
\text { raised. }\end{array}$ \\
\hline $\begin{array}{l}\text { Siha \& } \\
\text { Monroe } \\
(2006)\end{array}$ & $\begin{array}{l}1979- \\
2002\end{array}$ & $\begin{array}{l}\text { Explore state of } \\
\text { telecommuting to } \\
\text { date, identify } \\
\text { failure and success } \\
\text { factors }\end{array}$ & $\begin{array}{l}\text { Developed theoretical } \\
\text { model of antecedents and } \\
\text { outcomes of successful } \\
\text { telecommuting } \\
\text { initiatives. }\end{array}$ & $\begin{array}{l}\text { Need to better understand } \\
\text { organizational, } \\
\text { managerial, and worker } \\
\text { motivations. }\end{array}$ \\
\hline
\end{tabular}


Table 2. Recent Research on Telecommuting

\begin{tabular}{|c|c|c|c|}
\hline Author & Research Question(s) & \begin{tabular}{|l|l} 
Methodology \& \\
Sample
\end{tabular} & Main Findings \\
\hline Kakihara (2004) & $\begin{array}{l}\text { Discuss the emergence } \\
\text { of the mobile } \\
\text { professional }\end{array}$ & $\begin{array}{l}\text { Ad hoc observation } \\
\text { and interviews: } 62 \\
\text { mobile professionals } \\
\text { in Tokyo; } 3 \text { cases } \\
\text { presented in the } \\
\text { paper. }\end{array}$ & $\begin{array}{l}\text { Need to broaden our conception of } \\
\text { mobility; mobile professional } \\
\text { involves locational, operational, } \\
\text { and interactional mobility. }\end{array}$ \\
\hline $\begin{array}{l}\text { Perez, Sanchez } \\
\text { \& Pilar Jimenez } \\
\text { (2004) }\end{array}$ & $\begin{array}{l}\text { Develop theoretically- } \\
\text { based model of telework } \\
\text { adoption. }\end{array}$ & Conceptual & $\begin{array}{l}\text { Model of teleworking adoption } \\
\text { based on Technology Acceptance } \\
\text { Model (TAM). }\end{array}$ \\
\hline Cousins (2005) & $\begin{array}{l}\text { Explored practices of } \\
\text { individual nomadic } \\
\text { computing users after } \\
\text { implementation of a } \\
\text { nomadic computing } \\
\text { environment. }\end{array}$ & $\begin{array}{l}1 \text { case (financial } \\
\text { institution in USA); } \\
\text { observations, } \\
\text { documents, and } \\
\text { interviews: } 4 \text { loan } \\
\text { officer; } 2 \\
\text { interviewed again } 3 \\
\text { months after change } \\
\end{array}$ & $\begin{array}{l}\text { Although users experienced } \\
\text { contradictory outcomes as they } \\
\text { sought resolutions to the dilemmas } \\
\text { posed by work and nonwork } \\
\text { demands, all users reported } \\
\text { effectiveness in their computing } \\
\text { practices. }\end{array}$ \\
\hline $\begin{array}{l}\text { Golden \& Veiga } \\
\text { (2005) }\end{array}$ & $\begin{array}{l}\text { Reconcile inconsistent } \\
\text { findings in research on } \\
\text { telecommuter job } \\
\text { satisfaction. }\end{array}$ & $\begin{array}{l}\text { Survey: one firm, } \\
\text { data from } 321 \\
\text { telecommuters }\end{array}$ & $\begin{array}{l}\text { Curvilinear relationship between } \\
\text { extent of telecommuting and job } \\
\text { satisfaction. Relationship } \\
\text { moderated by task characteristics. }\end{array}$ \\
\hline $\begin{array}{l}\text { Jarvenpaa } \\
\text { (2005) }\end{array}$ & $\begin{array}{l}\text { Examine experiences of } \\
\text { mobile technology users } \\
\text { in Hong Kong, Japan, } \\
\text { Finland, and the United } \\
\text { States. }\end{array}$ & $\begin{array}{l}33 \text { international } \\
\text { focus groups with } \\
222 \text { urban mobile } \\
\text { devices }\end{array}$ & $\begin{array}{l}\text { Identifies eight central mobile } \\
\text { technology paradoxes that shape } \\
\text { user experience and behavior; } \\
\text { suggest possible design features } \\
\text { that relate to the paradoxes, and } \\
\text { discusses how these features could } \\
\text { be better managed. }\end{array}$ \\
\hline $\begin{array}{l}\text { Mazmanian } \\
(2005)\end{array}$ & $\begin{array}{l}\text { Examining use of } \\
\text { wireless email devices } \\
\text { among mobile } \\
\text { information } \\
\text { professionals and their } \\
\text { spouses, including } \\
\text { effects of social } \\
\text { presence, physical and } \\
\text { virtual interactions, and } \\
\text { public environments }\end{array}$ & $\begin{array}{l}69 \text { semi-structured } \\
\text { interviews in } 3 \\
\text { organizations with } \\
\text { mobile professionals }\end{array}$ & $\begin{array}{l}\text { People differentiate wireless e- } \\
\text { mail devices from other } \\
\text { communication technologies in } \\
\text { terms of patterns, norms, and } \\
\text { experience of use. } \\
\text { Participants report constant and } \\
\text { sustained interaction with their } \\
\text { devices, at all hours and locations } \\
\text { of their day. }\end{array}$ \\
\hline $\begin{array}{l}\text { Baker, Avery \& } \\
\text { Crawford (2006) }\end{array}$ & $\begin{array}{l}\text { Is there a relationship } \\
\text { between forms of } \\
\text { technology support and } \\
\text { employee reactions to } \\
\text { telecommuting? }\end{array}$ & $\begin{array}{l}\text { Survey: } 20 \text { firms in } \\
\text { Australia, } 50 \\
\text { respondents who } \\
\text { telecommute at least } \\
\text { one day per week }\end{array}$ & $\begin{array}{l}\text { Support more closely related to } \\
\text { technology has more impact on } \\
\text { reactions to telecommuting than } \\
\text { support less closely related to } \\
\text { technology. }\end{array}$ \\
\hline Golden (2006) & Examines role & Survey: one firm, & U-shaped relationship between \\
\hline
\end{tabular}


Table 2. Recent Research on Telecommuting

\begin{tabular}{|c|c|c|c|}
\hline & $\begin{array}{l}\text { relationships play in } \\
\text { mediating link between } \\
\text { extent of telecommuting } \\
\text { and job satisfaction. }\end{array}$ & $\begin{array}{l}\text { data from } 294 \\
\text { telecommuters }\end{array}$ & $\begin{array}{l}\text { extent of telecommuting and job } \\
\text { satisfaction, mediated by quality } \\
\text { of interactions in work-oriented } \\
\text { and family-oriented relationships. }\end{array}$ \\
\hline Madsen (2006) & $\begin{array}{l}\text { Investigate differences } \\
\text { in work family conflict } \\
\text { between telecommuters } \\
\text { and non-telecommuters. }\end{array}$ & $\begin{array}{l}\text { Survey of } \\
\text { telecommuters and } \\
\text { non-telecommuters } \\
\text { at seven firms in } \\
\text { Midwest USA }\end{array}$ & $\begin{array}{l}\text { Non-telecommuters have higher } \\
\text { levels of work-family conflict, } \\
\text { time-based conflict, strain-based } \\
\text { conflict, and higher perceptions of } \\
\text { work interference with family than } \\
\text { telecommuters do. Male have } \\
\text { higher levels of behaviour-based } \\
\text { conflict than females } \\
\text { telecommuters. }\end{array}$ \\
\hline $\begin{array}{l}\text { Scheitzer \& } \\
\text { Duxbury (2006) }\end{array}$ & $\begin{array}{l}\text { Assess state of } \\
\text { telecommuting in } \\
\text { Canada in } 1999 \text { and in } \\
2001 .\end{array}$ & $\begin{array}{l}\text { Survey data } \\
\text { collected in } 1999 \\
\text { and } 2001 \text { from over } \\
20,000 \text { employees \& } \\
\text { 6,300 employers in } \\
\text { Canada }\end{array}$ & $\begin{array}{l}\text { Increase in number of firms } \\
\text { offering telecommuting - from 3\% } \\
\text { in } 1999 \text { to } 7 \% \text { in } 2001 \text {. } \\
\text { Participants: highly educated, } \\
\text { well-paid, male and female } \\
\text { knowledge workers with } \\
\text { dependent care responsibilities. }\end{array}$ \\
\hline $\begin{array}{l}\text { Towers, } \\
\text { Duxbury, } \\
\text { Higgins \& } \\
\text { Thomas (2006) }\end{array}$ & $\begin{array}{l}\text { Investigate the shifting } \\
\text { boundaries between } \\
\text { home and work for non- } \\
\text { telecommuters using } \\
\text { mobile technology. }\end{array}$ & $\begin{array}{l}\text { Survey and } \\
\text { interview data from } \\
\text { a Canadian } \\
\text { government agency. } \\
845 \text { surveys and } 61 \\
\text { interviews }\end{array}$ & $\begin{array}{l}\text { Mobile technology enables } \\
\text { flexibility of timing and location } \\
\text { of work. Easier to accommodate } \\
\text { work and family but increases } \\
\text { expectations of both spheres and } \\
\text { leads to greater workload. }\end{array}$ \\
\hline Brodt (2007) & $\begin{array}{l}\text { Identify enablers and } \\
\text { barriers for successful } \\
\text { implementation of } \\
\text { mobile work in practice. }\end{array}$ & $\begin{array}{l}5 \text { cases; } \\
15 \text { in-depth } \\
\text { interviews }\end{array}$ & $\begin{array}{l}\text { Adequate skills, sufficient } \\
\text { commitment and a systematic } \\
\text { preparation are key enablers to the } \\
\text { success of mobile work } \\
\text { environments. } \\
\text { Potential barriers for mobile work } \\
\text { environments arise mainly from } \\
\text { the changes of work processes and } \\
\text { work styles of mobile workers. }\end{array}$ \\
\hline $\begin{array}{l}\text { Gajendran \& } \\
\text { Harrison (2007) }\end{array}$ & $\begin{array}{l}\text { Study consequences of } \\
\text { telecommuting for } \\
\text { individuals; through } \\
\text { what psychological } \\
\text { mechanisms do effects } \\
\text { occur; under what } \\
\text { conditions do strongest } \\
\text { effects occur. }\end{array}$ & $\begin{array}{l}\text { Meta-analysis of } 46 \\
\text { studies in natural } \\
\text { settings involving } \\
12,883 \text { employees }\end{array}$ & $\begin{array}{l}\text { Telecommuting has largely } \\
\text { beneficial consequences. Some } \\
\text { negative effects found with high- } \\
\text { intensity telecommuting (more } \\
\text { than } 2.5 \text { days/week). }\end{array}$ \\
\hline Golden (2007) & $\begin{array}{l}\text { Investigates whether } \\
\text { prevalence of } \\
\text { telecommuters in an } \\
\text { office impacts work } \\
\text { outcomes of non- } \\
\end{array}$ & $\begin{array}{l}\text { Survey of } 240 \\
\text { educated non- } \\
\text { telecommuting } \\
\text { professionals in a } \\
\text { high-technology }\end{array}$ & $\begin{array}{l}\text { Prevalence of telecommuting is } \\
\text { negatively associated with co- } \\
\text { worker satisfaction; relationship } \\
\text { influenced by amount of time co- } \\
\text { workers telecommute, level of }\end{array}$ \\
\hline
\end{tabular}


Table 2. Recent Research on Telecommuting

\begin{tabular}{|c|c|c|c|}
\hline & telecommuters. & company in the US & $\begin{array}{l}\text { FTF interactions and job } \\
\text { autonomy. }\end{array}$ \\
\hline $\begin{array}{l}\text { Hartig, Kylin \& } \\
\text { Johansson } \\
\text { (2007) }\end{array}$ & $\begin{array}{l}\text { Investigate tradeoffs } \\
\text { between stress } \\
\text { mitigation of } \\
\text { teleworking and possible } \\
\text { effect on restorative } \\
\text { function of home. }\end{array}$ & $\begin{array}{l}\text { Survey: } 58 \\
\text { teleworkers and } 43 \\
\text { non-teleworkers in } \\
\text { one Swedish } \\
\text { company }\end{array}$ & $\begin{array}{l}\text { Teleworkers and non-teleworkers } \\
\text { experience home as place of } \\
\text { restoration; teleworking women } \\
\text { report less, and men more, } \\
\text { effective restoration than non- } \\
\text { teleworking counterparts. }\end{array}$ \\
\hline $\begin{array}{l}\text { Lee, Shin \& } \\
\text { Higa (2007) }\end{array}$ & $\begin{array}{l}\text { Examine gap between } \\
\text { telework and central } \\
\text { work in accessing tacit } \\
\text { knowledge and in use of } \\
\text { communication media } \\
\text { for knowledge } \\
\text { exchange. }\end{array}$ & $\begin{array}{l}\text { Study in seven large } \\
\text { Japanese companies: } \\
58 \text { survey responses } \\
\text { and } 35 \text { interviewees: } \\
\text { telecommuters, and } \\
\text { mobile and satellite } \\
\text { office workers }\end{array}$ & $\begin{array}{l}\text { Significant discrepancies between } \\
\text { telework and central-work in } \\
\text { knowledge accessibility and in } \\
\text { patterns of media usage for } \\
\text { knowledge access. Teleworking } \\
\text { made it more difficult to access } \\
\text { tacit knowledge. }\end{array}$ \\
\hline $\begin{array}{l}\text { Sanchez, Perez, } \\
\text { Carnicer \& } \\
\text { Jimenez (2007) }\end{array}$ & $\begin{array}{l}\text { Explores the relationship } \\
\text { between teleworking } \\
\text { adoption, workplace } \\
\text { flexibility, and firm } \\
\text { performance. }\end{array}$ & $\begin{array}{l}\text { Structured } \\
\text { interviews: } \\
\text { managers at } 479 \\
\text { small and medium- } \\
\text { sized firms in } \\
\text { northwest Spain }\end{array}$ & $\begin{array}{l}\text { Firm performance is positively } \\
\text { related to teleworking programs. } \\
\text { Teleworking firms use more } \\
\text { flextime, have more employees } \\
\text { involved in job design, are more } \\
\text { intensively managed by results and } \\
\text { use more variable compensation. }\end{array}$ \\
\hline Araujo (2008) & $\begin{array}{l}\text { Investigates how } \\
\text { university lecturers deal } \\
\text { with space and time in } \\
\text { professional activities. }\end{array}$ & $\begin{array}{l}\text { Interviews: } 38 \\
\text { university lecturers } \\
\text { in two Portuguese } \\
\text { universities }\end{array}$ & $\begin{array}{l}\text { Use of ICT to construct space-time } \\
\text { work patterns has different } \\
\text { implications for each gender. }\end{array}$ \\
\hline Axtell (2008) & $\begin{array}{l}\text { Looks at differences } \\
\text { between train-based } \\
\text { mobile work and office } \\
\text { environments. Explore } \\
\text { the main impacts of train } \\
\text { mobile work on tasks. }\end{array}$ & $\begin{array}{l}\text { Surveys: } 350 \text { in UK } \\
\text { plus } 19 \text { interviews }\end{array}$ & $\begin{array}{l}\text { Majority of tasks conducted on } \\
\text { train are socially independent in } \\
\text { nature (without the need for } \\
\text { communication with others). } \\
\text { People make technological task } \\
\text { and contextual adaptations to } \\
\text { allow them to work to conduct } \\
\text { socially interdependent work } \\
\text { (need for communication with } \\
\text { others). }\end{array}$ \\
\hline $\begin{array}{l}\text { Bélanger \& } \\
\text { Allport (2008) }\end{array}$ & $\begin{array}{l}\text { Explore the effects of } \\
\text { improvements in } \\
\text { technology for } \\
\text { teleworkers on } \\
\text { communications } \\
\text { patterns. }\end{array}$ & $\begin{array}{l}\text { Case study: } 6 \\
\text { months pre and post } \\
\text { technology change } \\
\text { surveys and } \\
\text { interviews of } 13 \\
\text { teleworkers and } \\
\text { their management. }\end{array}$ & $\begin{array}{l}\text { Communication frequency among } \\
\text { group members was reduced after } \\
\text { the technology improvement but } \\
\text { became more centralized around } \\
\text { the district manager. }\end{array}$ \\
\hline $\begin{array}{l}\text { Golden, Veiga \& } \\
\text { Dino (2008) }\end{array}$ & $\begin{array}{l}\text { Examine professional } \\
\text { isolation of teleworkers } \\
\text { and the relationship with } \\
\text { job performance and } \\
\text { turnover intention. }\end{array}$ & $\begin{array}{l}\text { Survey: matched } \\
\text { sample of } 261 \\
\text { professional-level } \\
\text { teleworkers and } \\
\text { their managers in }\end{array}$ & $\begin{array}{l}\text { Teleworker professional isolation } \\
\text { is negatively associated with job } \\
\text { performance; impact is greater } \\
\text { with more time spent teleworking. } \\
\text { Unexpectedly, professional }\end{array}$ \\
\hline
\end{tabular}


Table 2. Recent Research on Telecommuting

\begin{tabular}{|c|c|c|c|}
\hline & & one high-tech firm & $\begin{array}{l}\text { isolation is related to lower } \\
\text { turnover intention. }\end{array}$ \\
\hline $\begin{array}{l}\text { Khalifa and } \\
\text { Davison (2008) }\end{array}$ & $\begin{array}{l}\text { Investigate the } \\
\text { applicability of TPB to } \\
\text { explain intended } \\
\text { continuance level of } \\
\text { telecommuting. }\end{array}$ & $\begin{array}{l}\text { Survey: } 101 \\
\text { telecommuters in } \\
\text { companies in North } \\
\text { America }\end{array}$ & $\begin{array}{l}\text { Attitude has significant effect on } \\
\text { intention but is negatively } \\
\text { moderated by habit; subjective } \\
\text { norms exert moderate effect on } \\
\text { intention to telecommute. }\end{array}$ \\
\hline $\begin{array}{l}\text { Sanchez, Perez, } \\
\text { Jimenez, } \\
\text { Carnicer (2008) }\end{array}$ & $\begin{array}{l}\text { Analyze contribution of } \\
\text { HR through adoption of } \\
\text { telework or workplace } \\
\text { flexibility practices to } \\
\text { firm performance. }\end{array}$ & $\begin{array}{l}\text { Survey: HR } \\
\text { managers and CEOs } \\
\text { in Spanish firms, } \\
156 \text { responses }\end{array}$ & $\begin{array}{l}\text { Access to HR commitment } \\
\text { practices lead to intensity of } \\
\text { telework adoption, which is } \\
\text { positively associated with firm } \\
\text { performance. }\end{array}$ \\
\hline $\begin{array}{l}\text { Sørensen \& Al- } \\
\text { Taitoon (2008) }\end{array}$ & $\begin{array}{l}\text { Explores how the } \\
\text { concept of } \\
\text { organizational usability } \\
\text { can contribute to better } \\
\text { understanding of the } \\
\text { organizational use of } \\
\text { mobile ICT. Investigate } \\
4 \text { mobile work options } \\
\text { for } 24 \mathrm{hr} \text { foreign } \\
\text { exchange trading, } \\
\text { including trade at home } \\
\text { option. }\end{array}$ & $\begin{array}{l}\text { Data collected from } \\
72 \text { employees of } \\
\text { 'MidEastBank' in- } \\
\text { depth interviews, } \\
\text { observations of } \\
\text { work activities, } \\
\text { analysis of voice } \\
\text { recordings of off- } \\
\text { premise transactions }\end{array}$ & $\begin{array}{l}\text { Home-trading with fixed location } \\
\text { PC, created tight physical coupling } \\
\text { between traders and the location of } \\
\text { trading led to temporal } \\
\text { discontinuity in the monitoring of } \\
\text { markets since traders could not be } \\
\text { in front of the desktop } \\
\text { continuously. Mobile trading, } \\
\text { which allowed work at home, } \\
\text { delivered sufficient loose coupling } \\
\text { of traders and locations to be } \\
\text { individually and organizationally } \\
\text { usable. }\end{array}$ \\
\hline $\begin{array}{l}\text { \{ Sørensen, } \\
2008 \# 232\}\end{array}$ & $\begin{array}{l}\text { Highlight key } \\
\text { management } \\
\text { challenges in the } \\
\text { mobile work } \\
\text { environment. }\end{array}$ & $\begin{array}{l}\text { Review of findings } \\
\text { from } 11 \text { previously } \\
\text { published case } \\
\text { studies of mobile } \\
\text { work }\end{array}$ & $\begin{array}{l}\text { Identified six different } \\
\text { challenges of seeking to gain } \\
\text { organisational efficiency, } \\
\text { including tensions between } \\
\text { individual discretion vs. } \\
\text { organizational control and } \\
\text { transformation of existing work } \\
\text { practices vs. cultivation of new } \\
\text { practices. }\end{array}$ \\
\hline $\begin{array}{l}\text { Wajcman et al. } \\
\text { (2008) }\end{array}$ & $\begin{array}{l}\text { Investigate proposition } \\
\text { that mobile phone } \\
\text { dissolves boundaries } \\
\text { separating work and } \\
\text { home, thus extending the } \\
\text { reach of work. }\end{array}$ & $\begin{array}{l}\text { Data collected from } \\
\text { individuals aged } 15 \\
\text { years and older in } \\
\text { households in } \\
\text { Australia, from } \\
\text { March to May 2007, } \\
\text { using a } \\
\text { questionnaire, a } \\
\text { phone log and a } \\
\text { time-diary }\end{array}$ & $\begin{array}{l}\text { Results indicate that mobile phone } \\
\text { is not primarily a work extension } \\
\text { device. The volume of work- } \\
\text { related traffic outside of hours of } \\
\text { employment was found to be low } \\
\text { and the main uses of the mobile } \\
\text { were for contacting family and } \\
\text { friends. }\end{array}$ \\
\hline Hislop (2009) & $\begin{array}{l}\text { Explores multi-location } \\
\text { work of teleworkers. }\end{array}$ & $\begin{array}{l}\text { Interviews: } 18 \\
\text { consultants from } 2 \\
\text { small UK } \\
\end{array}$ & $\begin{array}{l}\text { Spaces used by multi-location } \\
\text { workers vary significantly from } \\
\text { the workplaces of workers who }\end{array}$ \\
\hline
\end{tabular}


Table 2. Recent Research on Telecommuting

\begin{tabular}{|c|c|c|c|}
\hline & & consultancies. & $\begin{array}{l}\text { work predominantly from a single } \\
\text { location; multi-location workers } \\
\text { typically have to invest more } \\
\text { effort in creating and producing a } \\
\text { workplace in the locations that } \\
\text { their work takes them to. }\end{array}$ \\
\hline $\begin{array}{l}\text { Hornung, } \\
\text { Rousseau, } \\
\text { Glaser (2009) }\end{array}$ & $\begin{array}{l}\text { Study of idiosyncratic } \\
\text { deals (i-deals) where } \\
\text { workers shape their } \\
\text { employment } \\
\text { arrangements through } \\
\text { negotiating } \\
\text { individualized } \\
\text { employment conditions } \\
\text { facilitated by } \\
\text { telecommuting. }\end{array}$ & $\begin{array}{l}\text { Survey: } 263 \\
\text { supervisors } \\
\text { managing } \\
\text { telecommuting } \\
\text { employees in } \\
\text { German public } \\
\text { administration }\end{array}$ & $\begin{array}{l}\text { Results indicate that supervisors } \\
\text { can be motivated to authorize } \\
\text { effective i-deals in the context of } \\
\text { broader organizational programs } \\
\text { that legitimate and support their } \\
\text { negotiation. }\end{array}$ \\
\hline $\begin{array}{l}\text { Mayo, Pastor, } \\
\text { Gomez-Mejia, \& } \\
\text { Cruz (2009) }\end{array}$ & $\begin{array}{l}\text { Using a contingency } \\
\text { perspective and data } \\
\text { from } 122 \text { CEOs of } \\
\text { Spanish firms, this paper } \\
\text { examines what makes a } \\
\text { firm likely to adopt } \\
\text { telecommuting. }\end{array}$ & $\begin{array}{l}\text { Survey: } 102 \text { Spanish } \\
\text { \& Portuguese } \\
\text { CEO’s compared to } \\
\text { public business data }\end{array}$ & $\begin{array}{l}\text { Empirical evidence showed that } \\
\text { telecommuting is correlated with } \\
\text { small organizational size, a high } \\
\text { proportion of international } \\
\text { employees, and variable } \\
\text { compensation. }\end{array}$ \\
\hline O’Neill (2009) & $\begin{array}{l}\text { Explore personality and } \\
\text { motivational traits } \\
\text { related to teleworker } \\
\text { performance and } \\
\text { satisfaction . }\end{array}$ & $\begin{array}{l}\text { Survey: } 156 \\
\text { employees from } \\
8 \text { organizations in } \\
\text { Canada: } 78 \\
\text { teleworkers and } 78 \\
\text { non-teleworkers }\end{array}$ & $\begin{array}{l}\text { Certain personality and } \\
\text { motivational traits are related to } \\
\text { teleworker and non-teleworker } \\
\text { effectiveness, but some traits show } \\
\text { differential validity. There are also } \\
\text { situational differences (children, } \\
\text { tenure, etc.) }\end{array}$ \\
\hline $\begin{array}{l}\text { Hill, Erickson, } \\
\text { Holmes \& Ferris } \\
\text { (2010) }\end{array}$ & $\begin{array}{l}\text { Explores the influence } \\
\text { of workplace flexibility } \\
\text { on work-life conflict; } \\
\text { specifically examine } \\
\text { flexibility in where } \\
\text { (work-at-home) and } \\
\text { when (perceived } \\
\text { schedule flexibility) } \\
\text { workers engage in work- } \\
\text { related tasks. }\end{array}$ & $\begin{array}{l}\text { Survey: global } \\
\text { sample of workers in } \\
75 \text { countries }(\mathrm{N}= \\
24,436)\end{array}$ & $\begin{array}{l}\text { Across all four groups of } \\
\text { countries, the benefit of work-at- } \\
\text { home is increased when combined } \\
\text { with schedule flexibility. } \\
\text { Workplace flexibility is beneficial } \\
\text { both to individuals (in the form of } \\
\text { reduced work-life conflict) and to } \\
\text { businesses (in the form of capacity } \\
\text { for longer work hours). However, } \\
\text { work-at-home may be less } \\
\text { beneficial in countries with } \\
\text { collectivist cultures. }\end{array}$ \\
\hline $\begin{array}{l}\text { Hunton \& } \\
\text { Norman (2010) }\end{array}$ & $\begin{array}{l}\text { Investigate impact of } \\
\text { telework arrangements } \\
\text { on organizational } \\
\text { commitment and } \\
\text { relationship between } \\
\text { telework arrangements, }\end{array}$ & $\begin{array}{l}\text { Longitudinal study } \\
\text { ( } 2 \text { years) of } 160 \\
\text { participants (medical } \\
\text { coders) in } 5 \\
\text { hospitals : telework } \\
\text { arrangements across }\end{array}$ & $\begin{array}{l}\text { Participants in three of the } \\
\text { telework arrangements exhibited } \\
\text { significant increases in all aspects } \\
\text { of commitment. In groups } \\
\text { working exclusively at home, } \\
\text { organizational commitment was }\end{array}$ \\
\hline
\end{tabular}


Table 2. Recent Research on Telecommuting

\begin{tabular}{|l|l|l|l|}
\hline & $\begin{array}{l}\text { organizational } \\
\text { commitment, and task } \\
\text { performance. }\end{array}$ & $\begin{array}{l}\text { hospitals differed } \\
\text { with one control } \\
\text { group; unbalanced } \\
\text { randomized 2x2x1 } \\
\text { design }\end{array}$ & $\begin{array}{l}\text { equivalent to the control groups. } \\
\text { Found organizational commitment } \\
\text { mediates relationship between the } \\
\text { telework arrangements and task } \\
\text { performance. }\end{array}$ \\
\hline $\begin{array}{l}\text { Peters \& } \\
\text { Heusinkveld } 2010)\end{array}$ & $\begin{array}{l}\text { Examines the role of } \\
\text { managers in the } \\
\text { telework adoption } \\
\text { process; especially } \\
\text { influence of institutional } \\
\text { context on attitude } \\
\text { toward telecommuting. }\end{array}$ & $\begin{array}{l}\text { Survey: 96 CEOs } \\
\text { and 380 HR } \\
\text { managers in Dutch } \\
\text { organizations }\end{array}$ & $\begin{array}{l}\text { Perceived improvements of work } \\
\text { outcomes and social costs/benefits } \\
\text { vary among managers from } \\
\text { different 'occupational } \\
\text { communities', e.g., CEOs' beliefs } \\
\text { differ from HR managers'. } \\
\text { Telecommuting initiatives should } \\
\text { pay much more attention to the } \\
\text { institutional environment and } \\
\text { managers' subcultures. }\end{array}$ \\
\hline
\end{tabular}




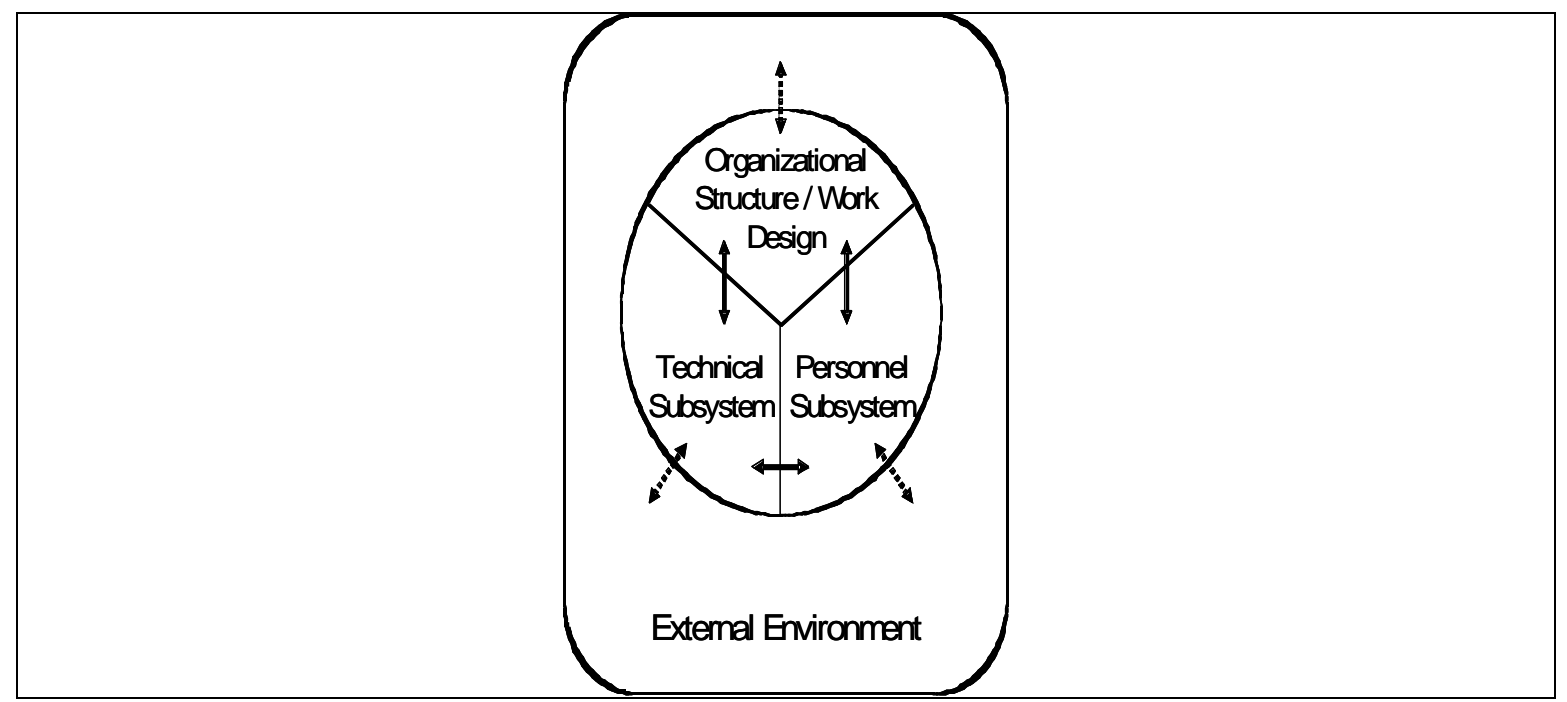

Figure 1. Basic Socio-technical Work System Model 
Table 3. Sample Telecommuting Antecedents and Outcomes across Levels of Analysis

\begin{tabular}{|c|c|c|c|}
\hline STS Subsystem & $\begin{array}{c}\text { Individual } \\
\text { Level of Analysis }\end{array}$ & $\begin{array}{c}\text { Group } \\
\text { Level of Analysis }\end{array}$ & $\begin{array}{c}\text { Organizational } \\
\text { Level of Analysis }\end{array}$ \\
\hline $\begin{array}{l}\text { Personnel } \\
\text { (Factors related to } \\
\text { personal, social } \\
\text { and cultural } \\
\text { characteristics or } \\
\text { issues affecting } \\
\text { telecommuters) }\end{array}$ & 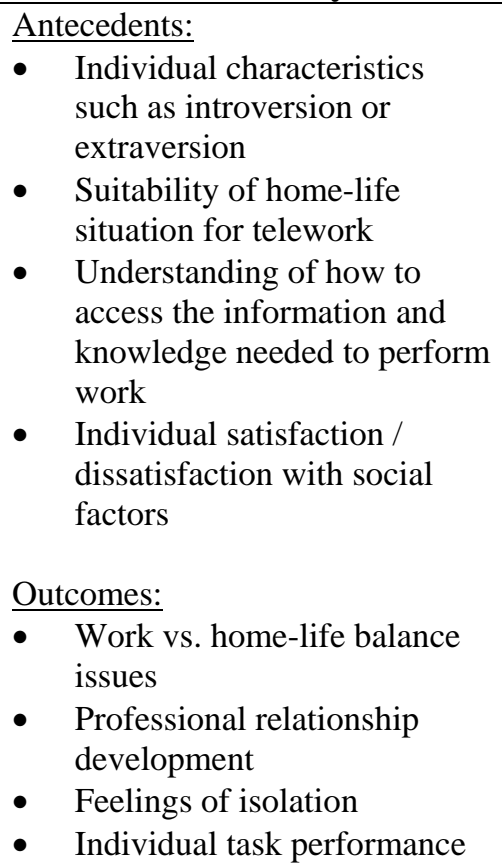 & $\begin{array}{ll}\text { Antecedents: } \\
\text { - } & \text { Work relationships } \\
\text { that facilitate group } \\
\text { work outcomes } \\
\text { - } \quad \text { Group cultural norms } \\
\text { - } \quad \text { Group knowledge } \\
\text { networking } \\
\text { - } \quad \text { Understanding of who } \\
\text { is doing what } \\
\text { - } \quad \text { Understanding of who } \\
\text { knows what } \\
\text { Outcomes: } \\
\text { - Professional } \\
\text { relationship } \\
\text { development } \\
\text { opportunities } \\
\text { - Group communication } \\
\text { - Group information and } \\
\text { knowledge exchange } \\
\text { Group performance }\end{array}$ & $\begin{array}{ll}\text { Outcomes: } \\
\text { - } & \text { Professional } \\
& \text { relationship } \\
& \text { development } \\
& \text { opportunities } \\
\text { - } & \text { Social network } \\
& \text { impacting access to } \\
\text { necessary } & \text { information and } \\
\text { recognition } \\
\text { Organizational } \\
\text { performance }\end{array}$ \\
\hline $\begin{array}{l}\text { Technical and } \\
\text { Work } \\
\text { (Factors } \\
\text { describing how } \\
\text { work is performed } \\
\text { and the types and } \\
\text { availability of ICT } \\
\text { and other } \\
\text { resources needed } \\
\text { to perform work) }\end{array}$ & 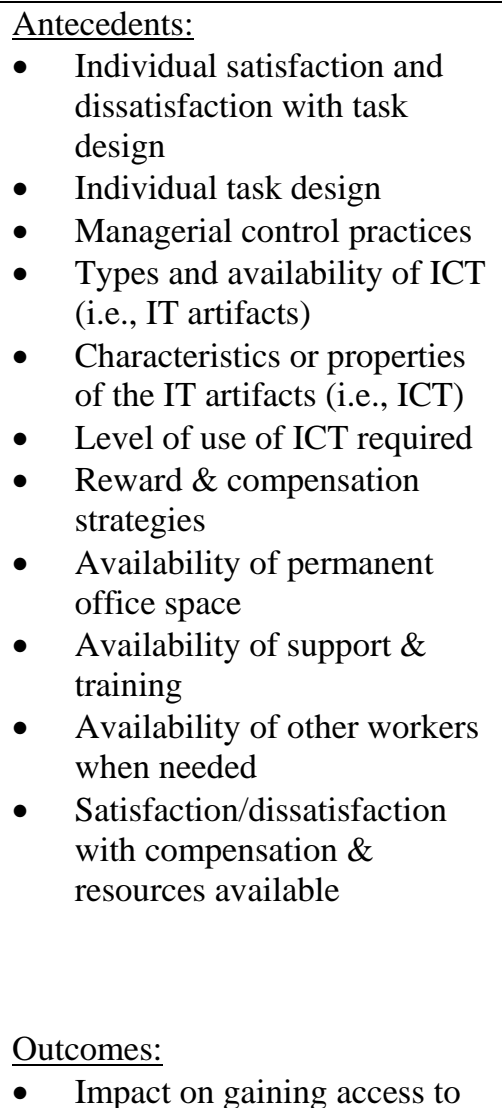 & $\begin{array}{ll}\text { Antecedents: } \\
\text { - } & \text { Group task design } \\
\text { - } & \text { facilitate group work } \\
\text { and collaboration } \\
\text { - } & \text { Group decision- } \\
\text { making processes } \\
\text { - } \\
\text { Managerial control } \\
\text { practices } \\
\text { - Group ICT available } \\
\text { (i.e., IT artifacts) } \\
\text { - } \quad \text { Characteristics or } \\
\text { properties of the IT } \\
\text { artifacts (i.e., ICT) for } \\
\text { group work } \\
\text { - Group reward \& } \\
\text { compensation } \\
\text { - Telework training } \\
\text { Level of availability of } \\
\text { good workers when } \\
\text { needed } \\
\text { Outcomes: } \\
-\quad \text { Structuring of work } \\
\text { - Availability of } \\
\text { workers when needed } \\
\text { Availability of }\end{array}$ & $\begin{array}{ll}\text { Antecedents: } \\
\text { - } & \text { Accessibility to } \\
& \text { large amounts of } \\
\text { information } \\
\text { - } & \text { Security policies } \\
\text { - } & \text { ICT operating } \\
\text { procedures } \\
\text { - } \quad \text { Value-adding } \\
\text { business processes } \\
\text { - } \text { Organizational ICT } \\
\text { available (i.e., IT } \\
\text { artifacts) } \\
\text { Characteristics or } \\
\text { properties of the IT } \\
\text { artifacts (i.e., ICT) } \\
\text { that support or affect } \\
\text { the organization } \\
\text { during } \\
\text { telecommuting } \\
\text { Support and training } \\
\text { for ICT } \\
\text { Training and support } \\
\text { for how to work in } \\
\text { telework } \\
\text { environment } \\
\text { Outcomes: }\end{array}$ \\
\hline
\end{tabular}




\begin{tabular}{|c|c|c|c|}
\hline & $\begin{array}{ll} & \text { required task information } \\
- & \text { Individual task performance } \\
\text { - } & \text { Access to organizational } \\
& \text { applications } \\
\text { - } & \text { Perceived quality of ICT } \\
& \text { support } \\
- & \text { Problems using ICT } \\
- & \text { Individual task performance } \\
\text { - } & \text { Satisfaction/dissatisfaction } \\
& \text { with compensation \& } \\
& \text { resources available }\end{array}$ & $\begin{array}{l}\text { information to group } \\
\text { when telecommuting } \\
\text { - } \quad \text { Quality of } \\
\text { communication in } \\
\text { virtual teams } \\
\text { - } \quad \text { Group task } \\
\text { performance } \\
\text { - Access speed for } \\
\text { group application } \\
\text { - Number of formal } \\
\text { meetings } \\
\text { - Time spent in formal } \\
\text { meetings } \\
\text { - Group task } \\
\text { performance }\end{array}$ & $\begin{array}{ll}\text { - } & \text { Ability to locate } \\
\text { people with specific } \\
\text { knowledge of task } \\
\text { information needed } \\
\text { - } & \text { Ability to access } \\
\text { specific to data, } \\
\text { information, } \\
\text { wisdom, \& } \\
\text { knowledge needed } \\
\text { - } \quad \begin{array}{l}\text { Impact on office } \\
\text { costs }\end{array} \\
\text { - } \\
\text { Impacts on ICT } \\
\text { support costs } \\
\text { Impacts on IT } \\
\text { infrastructure }\end{array}$ \\
\hline $\begin{array}{l}\text { Organizational } \\
\text { Structure } \\
\text { (Factors } \\
\text { describing } \\
\text { organizational } \\
\text { structure and } \\
\text { roles) }\end{array}$ & $\begin{array}{ll}\text { Antecedents: } \\
\text { - } & \text { Role clarity } \\
\text { - } & \text { Number of work projects to } \\
\text { - } & \text { Number of direct / indirect } \\
& \text { reporting relationships } \\
\text { - } & \text { Role variability } \\
\text { - } & \text { Number of formal meetings } \\
\text { - } & \text { Number of informal meetings } \\
& \text { / interruptions } \\
\text { Outcomes: } & \text { Change in available } \\
\text { - } & \text { individual time due to change } \\
\text { in the number of formal } \\
\text { meetings } \\
\text { - Impacts on informal } \\
\text { management feedback } \\
\text { Difficulty on managing a } \\
\text { dispersed team or group } \\
\text { (manager) } \\
\text { Individual task performance }\end{array}$ & 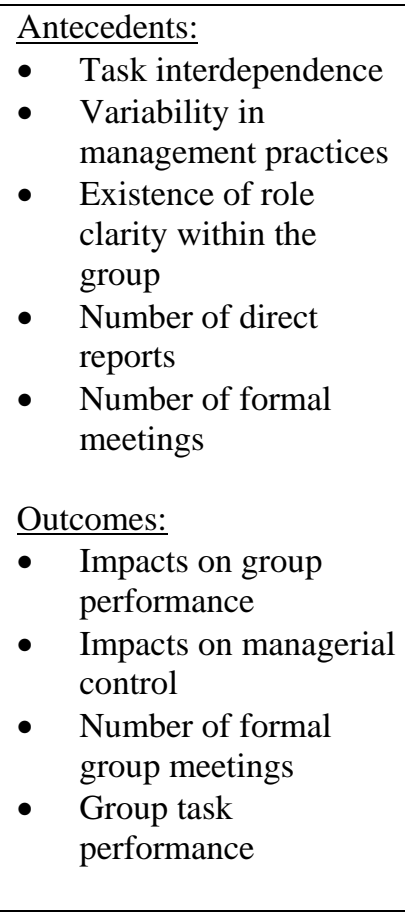 & $\begin{array}{ll}\text { Antecedents: } \\
\text { - } & \text { Variability in } \\
\text { management } \\
\text { practices over } \\
\text { multiple projects } \\
\text { that use the same } \\
\text { people } \\
\text { - } \quad \begin{array}{l}\text { Levels of } \\
\text { management }\end{array} \\
\\
\text { - } \\
\text { Outcomes: } \\
\text { Information security } \\
\text { impacts } \\
\text { Difficulty measuring } \\
\text { impacts of telework } \\
\text { Organizational } \\
\text { performance }\end{array}$ \\
\hline
\end{tabular}



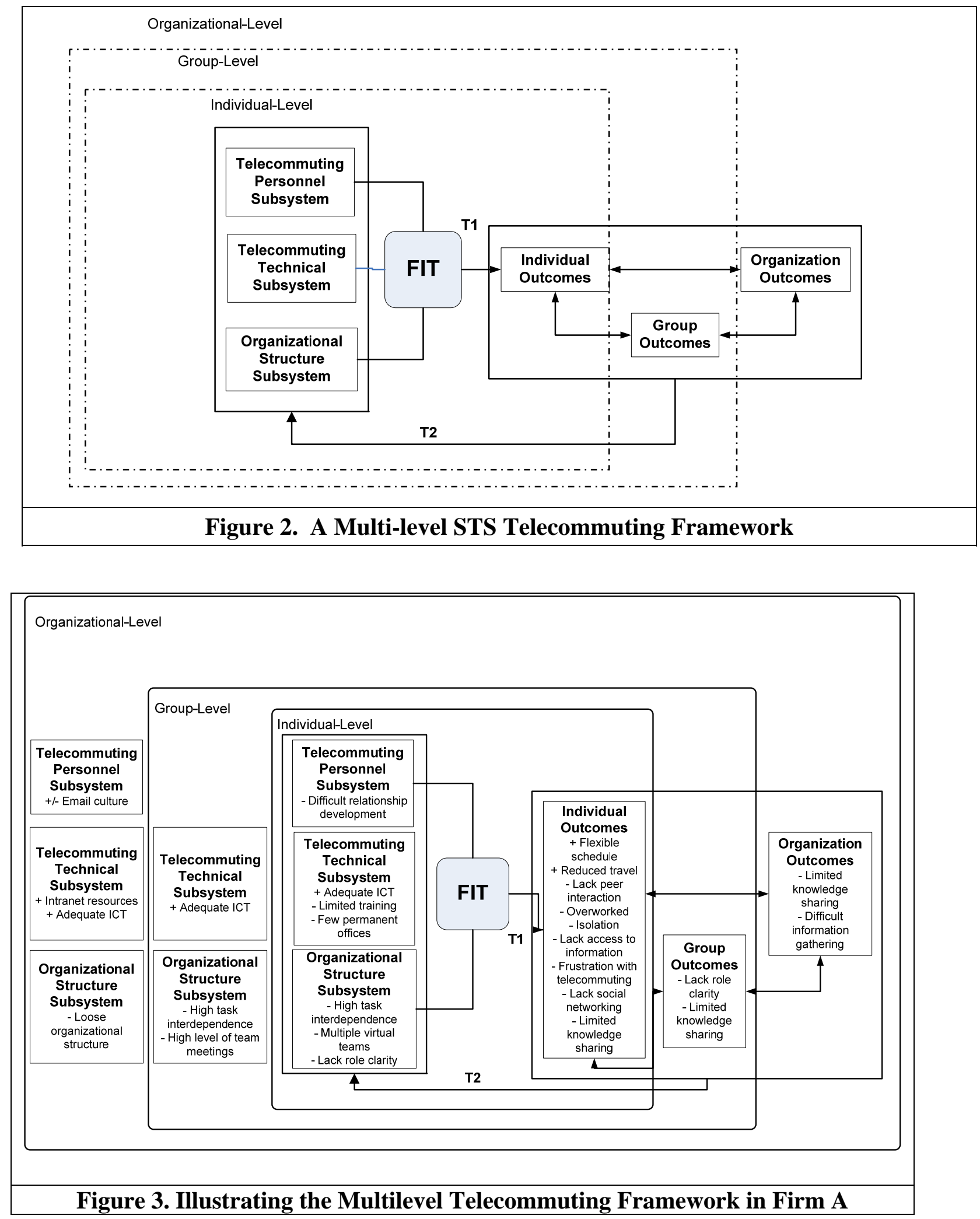


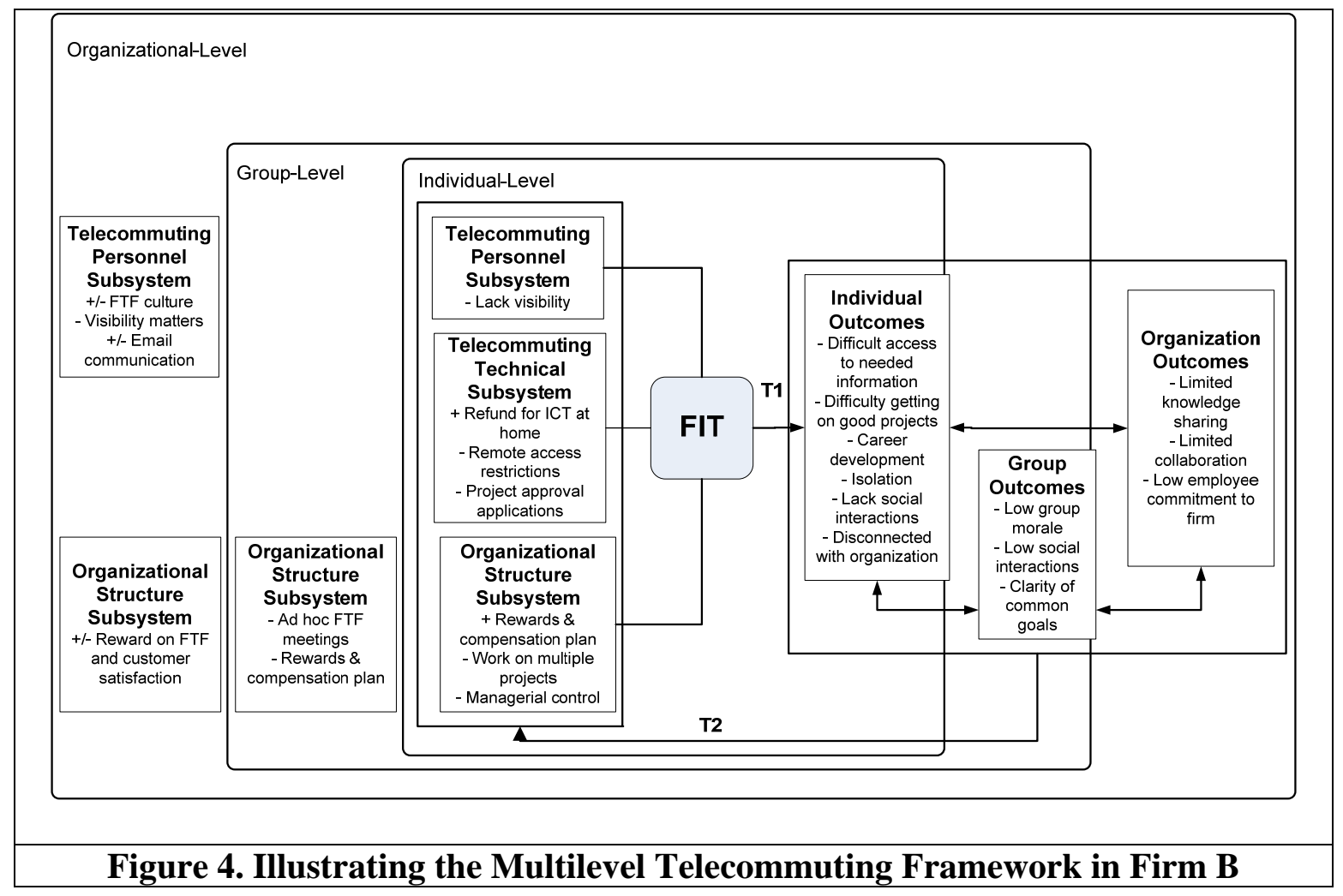

